\title{
ON CELL ORGANELLES IN TETRAHYMENA. WITH SPECIAL REFERENCE TO MITOCHONDRIA AND PEROXISOMES
}

\author{
by \\ JYTTE R. NILSSON \\ Institute of General Zoology, University of Copenhagen. \\ Universitetsparken 15. DK-2100 Copenhagen $\emptyset$
}

Keywords: Tetrahymena pyriformis, cell organelles, change in organelle composition, structure and function, mitochondria, peroxisomes

\begin{abstract}
In the ciliate, Tetrahymena pyriformis, the population of cell organelles shows variation during the culture cycle and when the cells are subjected to various treatments. New cell constituents may appear and the fine structure of mitochondria and peroxisomes may change. Such dynamic structural changes are described and reviewed in relation to physiological and biochemical studies on Tetrahymena. The cell organelles discussed are about $\mathrm{I} \mu \mathrm{m}$ in diameter or smaller; reference is also made to the nucleolar organization which is the most sensitive indicator of the physiological state of the cells. The presumed distribution of the various cell organelles in subcellular fractions of Tetrahymena is mentioned, since dependent on the pretreatment of the cells, especially the mitochondrial and peroxisomal fractions may be contaminated to varying degrees with other cell organelles.

The purpose of the review is to demonstrate that a correlation exists between the structure and function of cell organelles, especially mitochondria and peroxisomes. and that the overall fine structure of a cell reflects its physiological state.
\end{abstract}

\section{INTRODUCTION}

With different growth conditions the population of cell organelles varies in Tetrahymena and structural changes may occur in some organelles. The purpose of the present review is to demonstrate that there is a correlation between the fine structure of a cell and its physiological

\footnotetext{
- Part of this work was carried out at The Biological Institute of the Carlsberg Foundation. Tagensvej 16, DK-2200 Copenhagen N. Denmark.
}

state. The condition for making such a correlation is that the growth characteristics of the cell population are determined before and after withdrawal of samples for electron microscopy. The structural analysis of the cell organelles will be based mainly on the author's own work * on Tetrahymena grown under standard conditions, as outlined below, whereas the correlation between structure and function of the cell organelles will be discussed mainly with refer- 
Figure la-i. Presentation of the various cytoplasmic constituents of Tetrahymena pyriformis: some are permanent structures whereas others appear under certain conditions as discussed in the text.

The permanent organelles are: mitochondria associated with rough endoplasmic reticulum (Figure a), peroxisomes (Figure b), mucocysts, shown in the intact and extruding form (figure c), ribosomes (arrows) associated with endoplasmic reticulum or free in the cytoplasm (Figure d), and golgi complexes closely associated with mitochondria (Figure e). Structures not permanently present are: glycogen particles (arrows) which are larger than ribosomes (Figure f), lipid droplets (Figure g), dense granules of varying electron density (Figure h), and autophagic vacuoles (Figure i). Mitochondria (M), rough endoplasmic reticulum (ER). (Bar $=0.5 \mu \mathrm{m}$ ).

ence to biochemical investigations. After a general presentation of the cell organelles (section 2) the structural changes of Tetrahymena during the culture cycle (section 3) and in response to various treatments (section 4 ) will be discussed. The presumed distribution of the cell organelles in subcellular fractions of Tetrahymena will be mentioned since, dependent on the physiological state of the cells, the mitochondrial and peroxisomal fractions may be contaminated to varying degrees with other cell organelles.

\section{THE CELL ORGANELLES}

The cell organelles to be discussed are all of a size about $1 \mu \mathrm{m}$ in diameter, or smaller; food vacuoles and lysosomes in Tetrahymena have been reviewed recently (97). A brief characterization of the various organelles (Figure 1) will be given in the following. THE MITOCHONDRIA (Figure la) are composed of a double membrane system of which the inner membrane, enclosing the matrix, forms the typical tubular structures. Mitochondria are autonomous organelles with independent DNA $(110,137,131,136,111,14$, $41,13)$ and RNA species $(133,134,18,46,135$, 13); they are capable of protein synthesis (2, 146 , 13). Replication of mitochondrial DNA occurs throughout the cell cycle $(111,13)$, although synchronous replication is induced when $24-\mathrm{h}$ starved cells are transferred to fresh growth medium (38). Mitochondria divide by binary fission (60) and they are sensitive to treatment with ethidium bromide $(16,81,58,77)$. The organelles may play a role in the intracellular control of ions $(56,101)$, thus isolated mitochondria accumulate calcium at the expense of energy (22); the electron dense core found in mitochondria under unfavourable conditions $(117,32,36$, $33,92,101)$ may represent accumulated inorganic material (101). For reviews on the respira- tion of Tetrahymena and the respiratory components of its mitochondria see J. F. RYLEY (118), W. F. Danforth (29), and D. Lloyd (77). The PEROXISOMEs (Figure lb) are limited by a single membrane enclosing a finely granulated content. The organelle was first characterized biochemically $(54,7,31,86)$ and later morphologically $(6$, $83,85,143,88,92)$. Peroxisomes are nonphosphorylating, respiratory organelles $(30)$ containing enzymes which produce and utilize hydrogen peroxide, and enzymes of the glyoxylate bypass of the tricarboxylate cycle $(54,86$, $53,83,30,85$ ); enzymatic activity of the organelles has also been demonstrated cytochemically $(130,62)$. Peroxisomes are apparently formed by sequestration from the endoplasmic reticulum (92) as found in liver cells $(30,108)$ where, however, biochemical studies $(63,64)$ indicate that the marker enzyme, catalase, is synthesized outside the peroxisomes but that completion of the molecule occurs within the organelles; disconnection of forming peroxisomes from the endoplasmic reticulum during homogenization could explain these findings. THE MUCOCYSTS (Figure 1c) are cortical organelles; they are shown in the intact and extruding form. Mucocysts have been studied extensively both structurally $(140,3,143,144,122,123$, $120,92)$ and chemically $(1,50)$; however, the biogenesis of the organelles has not been revealed in detail. Tetrahymena contains about 1000 mucocysts; the extruded mucocyst material binds the cationic dye, alcian blue $(90,92,100$, 138 ), and the possible role of this material in nutrient uptake has been discussed $(92,97)$. The mucocysts extrude their contents in response to a variety of stimuli and the discharged material is an annoying contaminant in cell homogenates; these organelles will not be discussed further. THE RIBOSOMES (Figure 1d) are found free in the cytoplasm or bound to the endoplasmic reticu- 

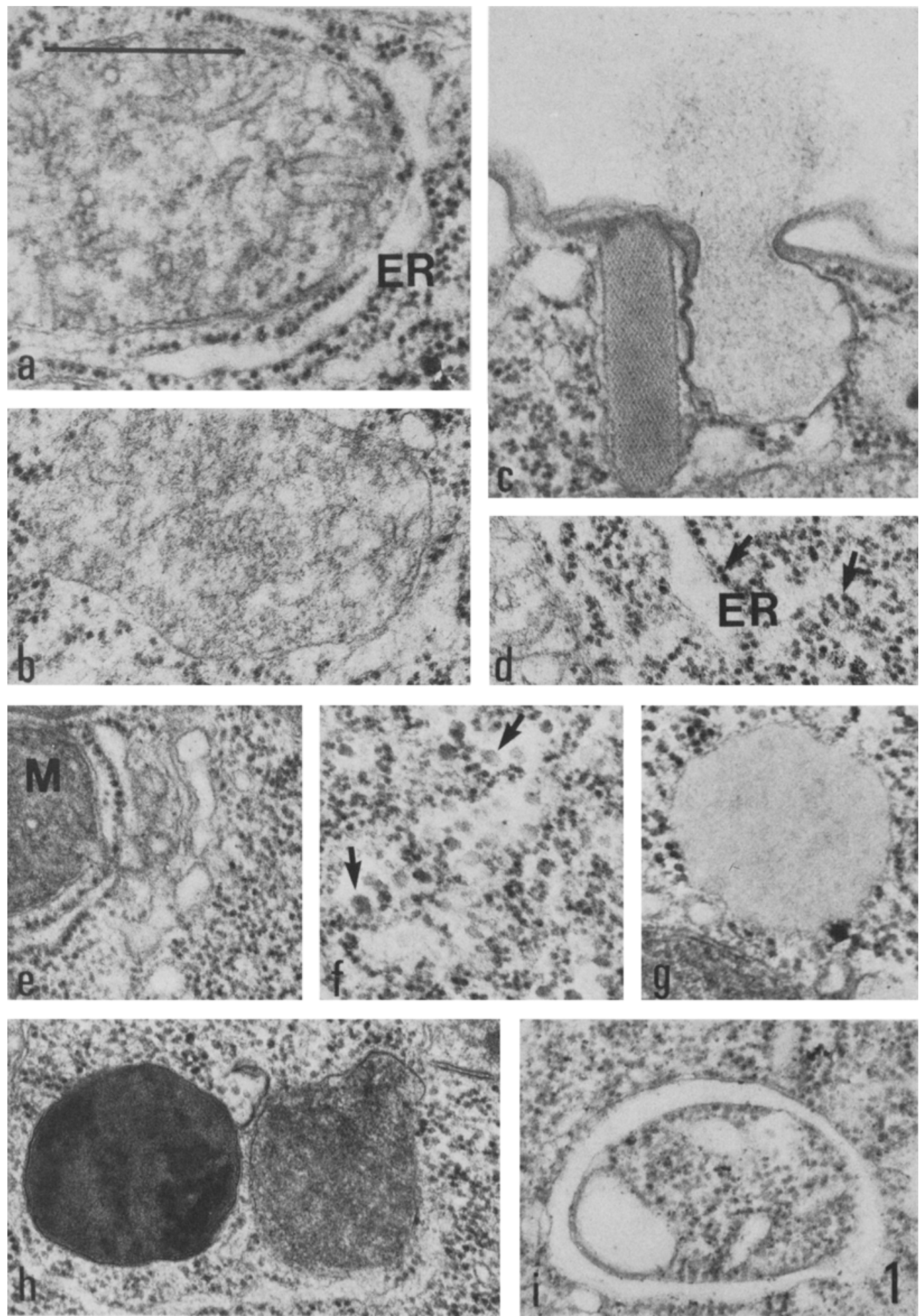
lum, depending on their associated messenger RNAs. The quantity of ribosomes varies with the physiological state of the cells (66). THE GOLGi COMPLEXes (Figure 1e) are inconspicuous organelles closely associated with mitochondria $(45,43,92,44,97)$. The forming face is a differentiated area of the rough endoplasmic reticulum associated with mitochondria, and the Golgi complex shows a distinct polarity with increasing membrane thickness towards the maturing face. The Golgi complexes in Tetrahymena probably play the universal role of packaging hydrolytic enzymes in primary lysosomes, and also of modifying membranes, from the type of the endoplasmic reticulum to the type of the plasma membrane, during formation of membrane renewal vesicles for the plasma and food vacuolar membranes (92). The early description of Golgi complexes in conjugating Tetrahymena (34) may represent stacks of reserve membrane vesicles, typical of these cells (42). During cell fractionations, Golgi complexes may sediment with mitochondria due to their close association with this organelle, alternatively they may sediment with the microsome fraction, unless they become disrupted, as found for liver cells (51) where portions of the Golgi comples are found in both fractions. In Tetrahy. mena the finding of phosphocholine transferase activity (129) in the mitochondrial fraction (see Table I) indicates sedimentation of Golgi complexes in this fraction, whereas the finding (142) that the food vacuolar membrane shows closer similarity to membranes of the microsome fraction than to that of isolated cilia, representing the plasma membrane, may indicate sedimentation of Golgi complexes, or parts of these, in the microsome fraction $(92,97)$. GLYCOGEN PARTICLES (Figure 1f) are larger than ribosomes and stain less intensely with routine contrasting methods. Native glycogen from Tetrahymena has been characterized (5) and the presence in situ of $\alpha$ - and $\beta$-particles has been demonstrated (132). Tetrahymena may contain large amounts of glycogen $(118,80,73,119,72,71,127)$. LIPID DROPLETS (Figure $\mathrm{lg}$ ) are usually of low electron density; they represent stores of triacylglycerol and are abundant in cells from the stationary growth phase $(4,139,72,71,12)$. SMall electron dense granules (Figure $1 \mathrm{~h}$ ) have contents of varying electron density. They are limited by a membrane which in structure resembles that of the plasma, and food vacuolar, membrane (101). The granules appear in the stationary growth phase and their presumed role in ion-regulation will be discussed. THE AUTOPhaGiC vacuoles (Figure 1i), the last type of organelles to be discussed, are small vacuoles enclosing portions of cytoplasm $(32,72,88,89$, 33,92 ) destined for digestion; thus, they are a kind of lysosomes.

Not all these cell organelles are found in Tetrahymena in all stages of growth; furthermore, those organelles permanently present may change in structure as will be outlined in the following. Although the cell nucleus is not considered in this review, reference will be made to the nucleolar organization because it is the most sensitive indicator of the physiological state of Tetrahymena; the direct relationship between the nucleolar structure and the production of ribosomes has been reported repeatedly $(15,103$, $121,66,92,93,67)$.

\section{THE CULTURE CYCLE}

The growth pattern of Tetrahymena pyriformis GL-8 (11) under standard conditions is shown in Figure 2. The growth medium is $2 \%$ proteose peptone enriched with $0.1 \%$ liver extract and inorganic salts (112); the cultures are aerated and shaken at $28^{\circ} \mathrm{C}$. After inoculation ( 200 cells $/ \mathrm{ml}$ ) follows a short lag period before the cells enter the log. phase, i.e. exponential cell multiplication (generation time less than $3 \mathrm{~h}$ ), up to a cell density of about 150,000 cells $/ \mathrm{ml}$; at this transition stage the cells enter the early stationary phase of growth for additionally 2-3 cell doublings at a decreased rate up to a cell density of $800,000-1,000,000$ cells $/ \mathrm{ml}$ which marks the true stationary phase. This high cell density is maintained for about $36 \mathrm{~h}$ after which the onset of cell deaths marks the decline phase. The transition point, or entry into the early stationary phase, is associated light microscopically with the appearance of small, refractile granules which increase in number with time, initially they are found in the anterior end of the cells and later distributed throughout the cells (102), as indicated in Figure 3. The appearance of the granules is invariably correlated with an increased cell generation time, thus they repre- 
sent a sensitive light microscopical marker for the physiological state of the cells. Since the fine structure of Tetrahymena may vary with the fixation procedure $(89,92)$ it is important to mention that all illustrations are of cells fixed in glutaraldehyde followed by osmium tetroxide (92).

The fine structure of Tetrahymena in different phases of the culture cycle is shown in Figure 4. In the log. phase (Figure 4a), the mitochondria and peroxisomes are of low electron density, i.e. they are of the 'light' type $(89,92)$; the nucleus contains numerous small nucleoli and ribosomes are abundant as typical in rapidly growing cells. At the transition (Figure 4b) into the early stationary phase. the mitochondria are of higher electron density, i.e. they are of the 'dense' type $(89,92)$, whereas the peroxisomes remain of the light type; the nucleoli are enlarged and lipid droplets (not shown) appear. In the early stationary phase (Figure 4c) where the rate of proliferation has decreased, mitochondria as well as peroxisomes are of the dense type; the nucleoli form small fusion bodies and the cells contain glycogen particles, lipid droplets, and small dense granules. In the stationary phase ( $\mathrm{Fi}$ gure $4 d$ ) where cell proliferation has ceased, the

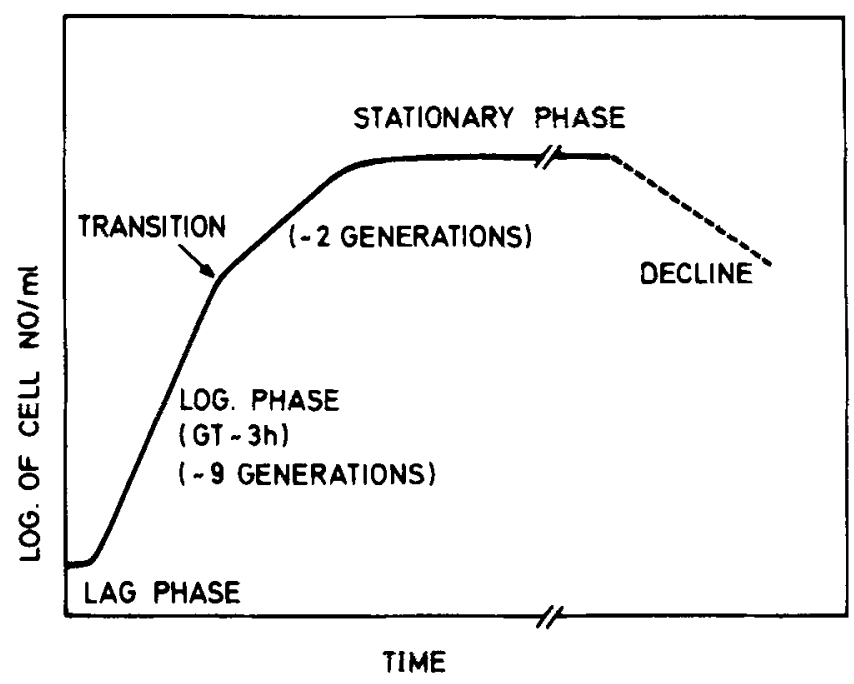

Figure 2. Typical growth pattern of a culture of Tetrahymena pyriformis.

The various growth phases of the culture cycle are indicated on the curve, representing cell density plotted against time: the phases are defined according to the rate of increase, or decrease, in the relative number of cells per $\mathrm{ml}$. Note the transition point marking the abrupt alteration in the rate of cell proliferation.
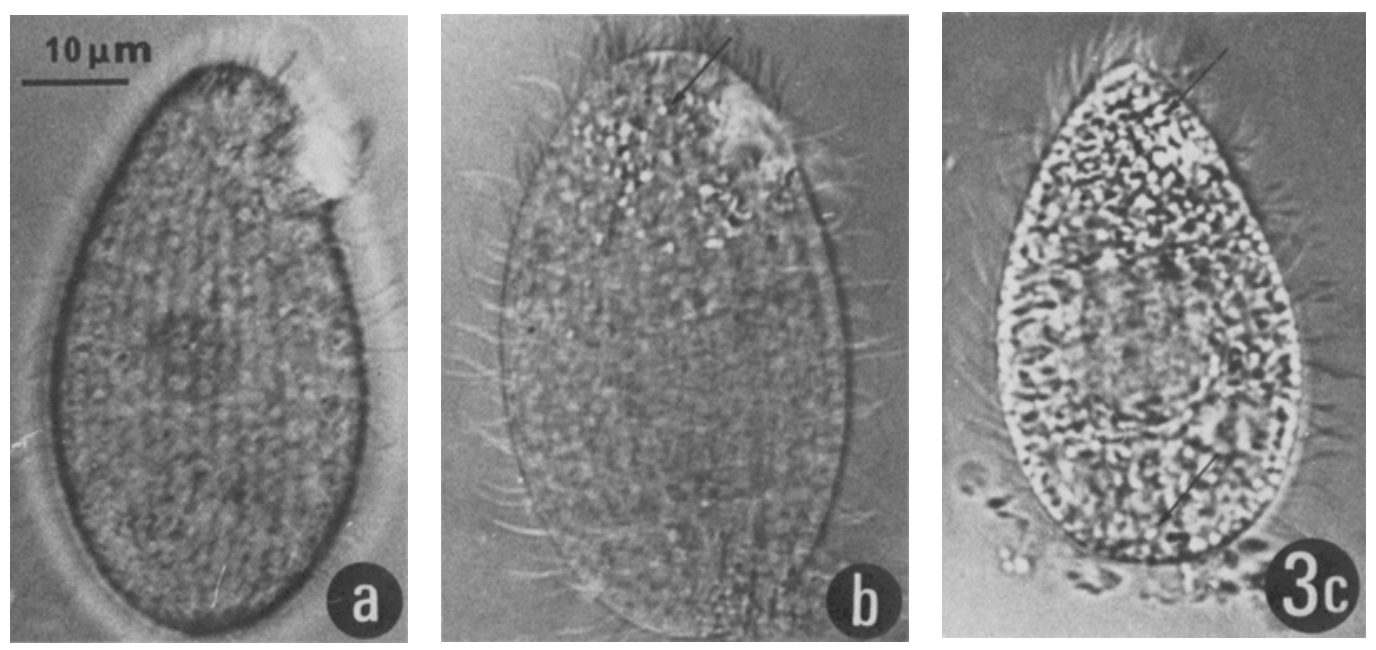

Figure $3 a-c$. Light micrographs illustrating the cyclic appearance of small, refractile granules in Tetrahymena fixed briefly in osmium tetroxide. Granules are absent in rapidly multiplying (log. phase) cells (Figure a); however, they appear in cells from the early stationary phase of growth, initially in the anterior region of the cell (Figure b), and as the granules continue to accumulate they become distributed throughout the cells in the stationary phase of growth (Figure c). Reproduced from (92). 

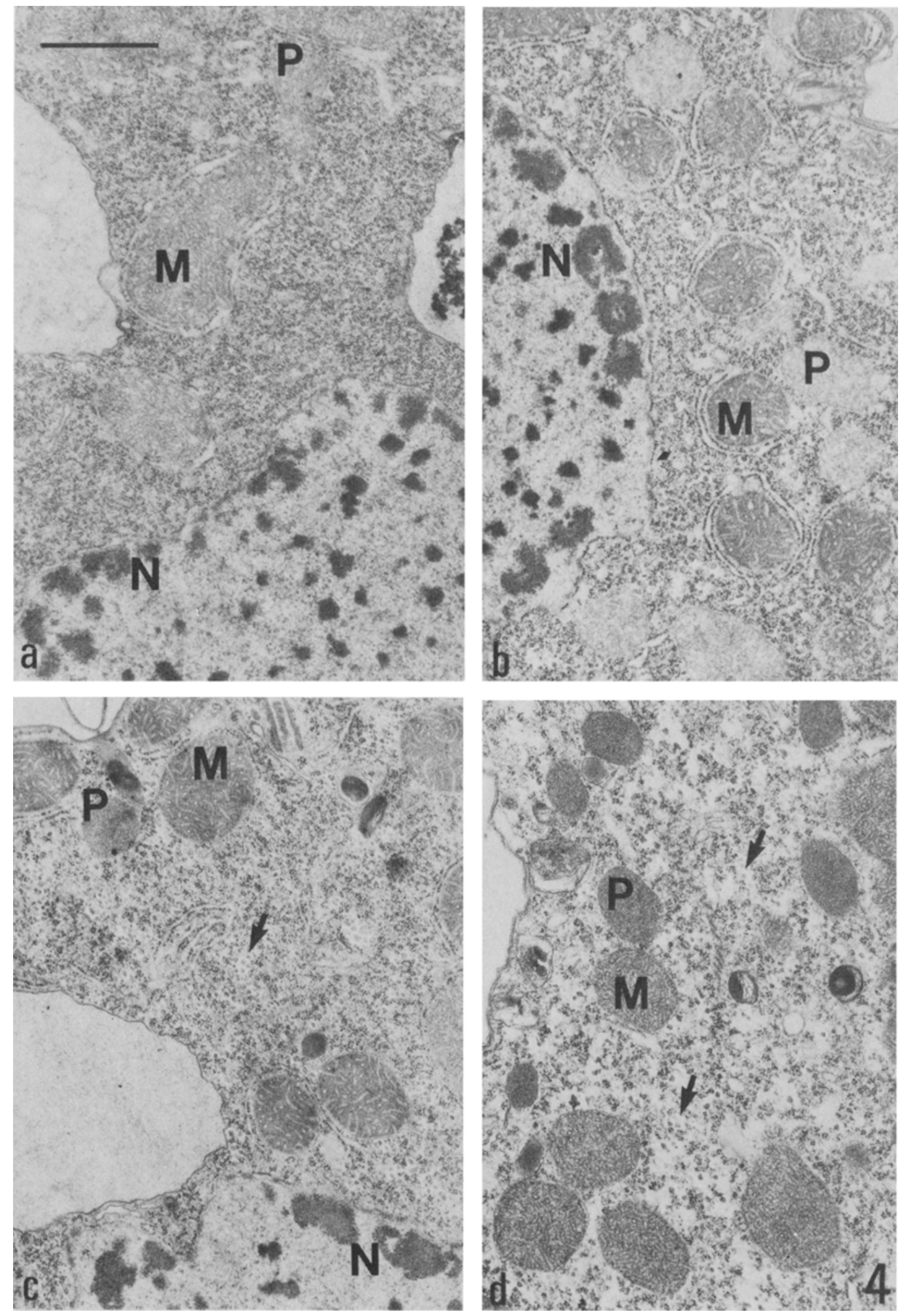

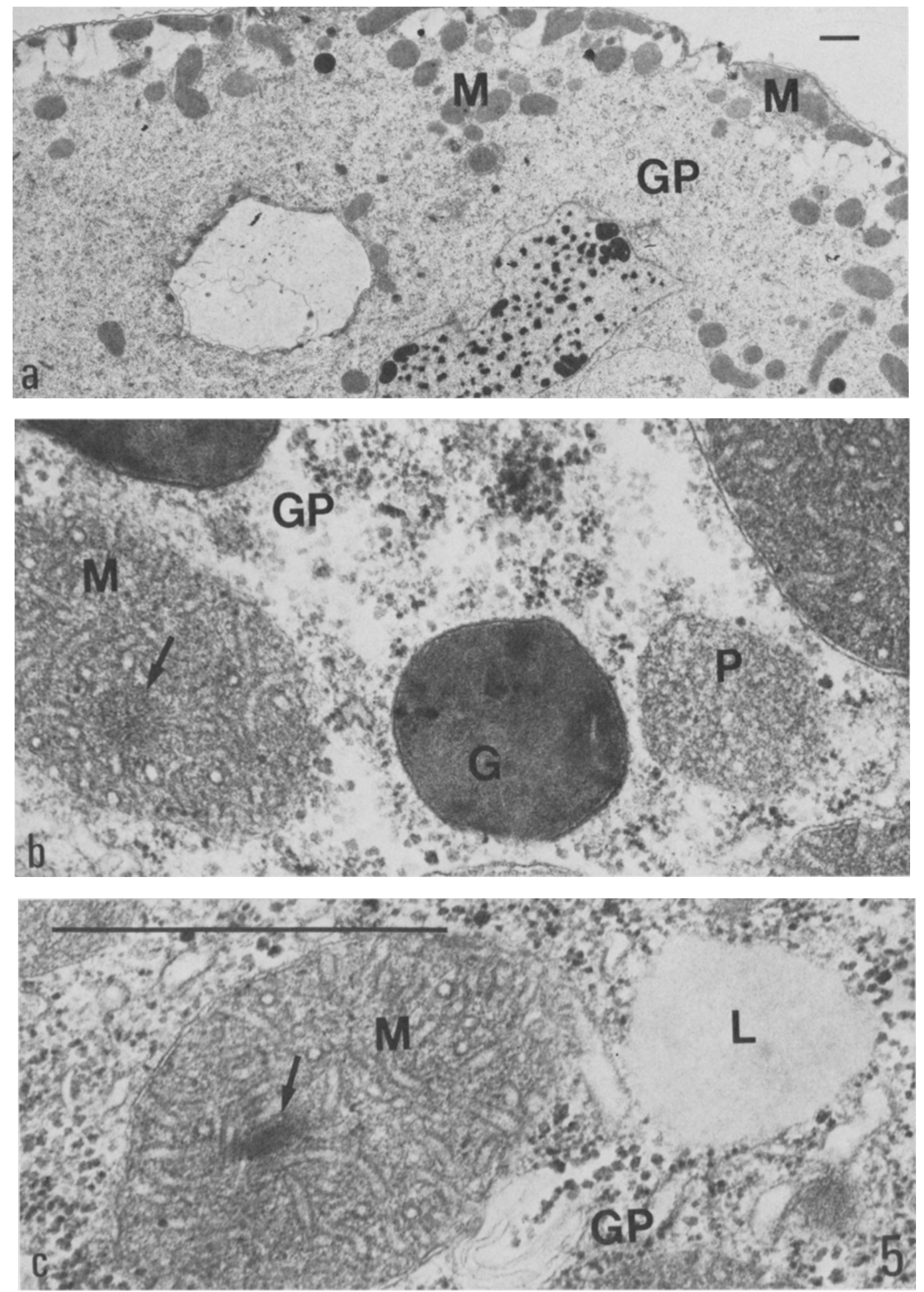
Figure $4 a-d$. Sections of Tetrahymena in different phases of growth.

In the log. phase (Figure a) mitochondria and peroxisomes are of the light type, ribosomes are abundant, and the nucleoli are small. At the transition stage (about 150,000 cells $/ \mathrm{ml}$ ) the mitochondria are dense and the peroxisomes remain light type; the nucleoli are slightly enlarged (Figure b). In the early stationary phase $(280,000$ cells $/ \mathrm{ml})$ the mitochondria and peroxisomes are dense type (Figure c), glycogen particles (arrow) and small dense granules are seen; the nucleoli have fused. In the stationary phase (no cell proliferation) the mitochondria and peroxisomes are dense (Figure d) and glycogen particles (arrows) form islands in the cytoplasm. Mitochondria $(M)$, peroxisomes $(P)$, nucleoli $(N) .(B a r=1 \mu \mathrm{m})$.

Figure $5 \mathrm{a}-\mathrm{c}$. Sections of Tetrahymena late in the stationary phase of growth.

The typical feature is the large amount of glycogen, confining larger organelles to islands in the cytoplasm (Figure a); the nucleoli have formed fusion bodies. Mitochondria and peroxisomes are dense type (Figure b) and the former organelles may have a dense core (arrow); lipid droplets (Figure $\mathrm{c}$ ) and dense granules (Figure d) are present and there are few ribosomes. Mitochondria $(M)$, peroxisomes $(P)$, dense granules $(G)$, and glycogen particles $(G P)$. (Bar $=1 \mu \mathrm{m})$.

mitochondria and peroxisomes remain of the dense type and there is a progressive accumulation of glycogen particles, forming small islands in the cytoplasm, and fusion of nucleoli (not shown). Late in the stationary phase (Figures $5 b$, 5c) lipid droplets and small dense granules are numerous, whereas there are few ribosomes and sparse endoplasmic reticulum; the mitochondria may contain a dense core (Figure 5c) and they are confined to the cortical region and to small islands due to large amounts of glycogen particles (Figure 5a). Glycogen may comprise more than $25 \%$ of the weight of Tetrahymena $(118,80,124,73,119,71)$. Thus, from the transition point and onwards marked changes occur in the population of cell constituents and in the structure of mitochondria, peroxisomes, and nucleoli.

The structural changes observed in Tetrahymena, as it passes through the culture cycle, is a reflection of a changing cellular physiology. Thus, the rate of oxygen consumption is decreased in stationary phase cells $(109,55,29$, $49,78,71)$, as compared to log. phase cells; furthermore, stationary phase cells have a high capacity for glyconeogenesis, i.e. the conversion of lipid into glycogen $(54,73,53,83,71,127)$, which morphologically correlates with the presence of glycogen particles. Considered in relation to the physiology of the cells, the fine structure of mitochondria and peroxisomes indicates that the dense type of mitochondria correlates with a low activity of the organelle in oxidative phosphorylation, and likewise that the dense type of peroxisomes correlates with activity of the glyconeogenic enzymes in this organelle (92). In cells from the log. and stationary phase of growth both organelles appear in the corresponding type, light or dense, respectively (Figures $6 \mathrm{a}, 6 \mathrm{c}, 6 \mathrm{~d}$ ); however, this relationship is not observed in the transition stage (Figure 6b). How may structure and function be related to this point of the culture cycle? In Tetrahymena the enzymes of the glyoxylate bypass of the tricarboxylate cycle are distributed between mitochondria and peroxisomes (86) which means that substrate must pass from mitochondria to the peroxisomes and

Figure $6 \mathrm{a}-\mathrm{d}$. Structural relation of mitochondria and peroxisomes in Tetrahymena in various phases of the culture cycle.

In the log. phase (Figure a) both organelles are of the light type, typical of rapidly multiplying cells. At the transition stage $(160,000$ cells $/ \mathrm{ml})$ the mitochondria have changed to the dense type, whereas the peroxisomes remain light (Figure b). In the early stationary phase both mitochondria and peroxisomes are of the dense type (Figure c); glycogen particles are present. Late in the stationary phase (Figure d) mitochondria and peroxisomes remain dense, glycogen is abundant and ribosomes are few in number. Mitochondria (M), peroxisomes (P), glycogen particles (arrows), ribosomes $(\mathrm{R})$, dense granules $(\mathrm{G})$. (Bar $=0.5 \mu \mathrm{m})$. 

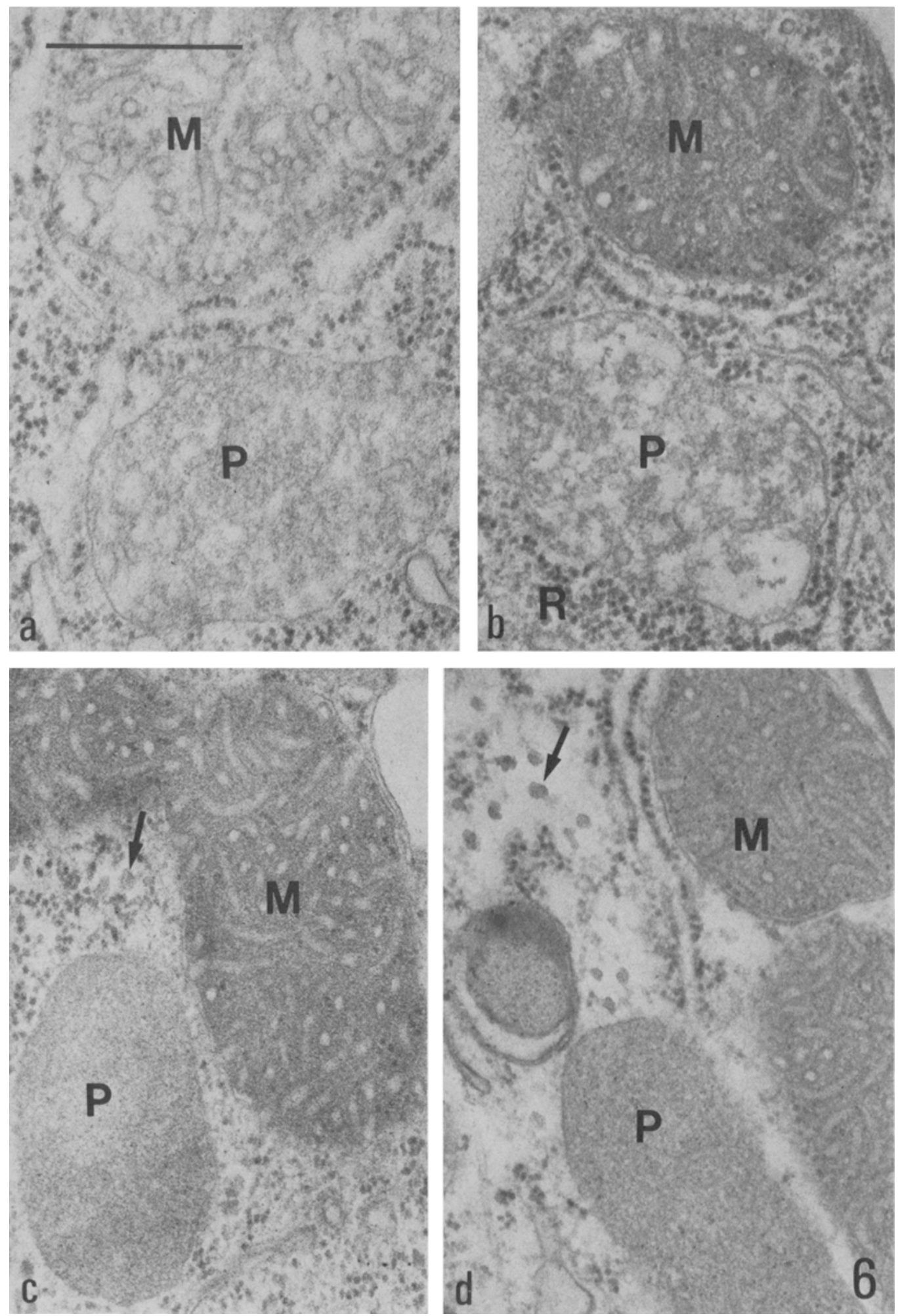
Table I

Mitochondrial and peroxisomal enzymes with indication of their activity: constant (C), or maximal in logaritmic (L) or in stationary (S) growth phase

\begin{tabular}{|c|c|c|c|}
\hline & Mitochondria & & Peroxisomes \\
\hline \multirow[t]{4}{*}{ (S) } & citrate synthase (53) & (S) & isocitrate lyase $(53.79)$ \\
\hline & aconitase & (S) & malate synthase $(53,79)$ \\
\hline & succinate dehydrogenase & (C) & isocitrate dehydrogenase (79) \\
\hline & acetyl-CoA synthase & & acetyl-CoA synthase \\
\hline \multirow[t]{2}{*}{ (C) } & fumarase (79) & & D-amino acid oxidase \\
\hline & malate dehydrogenase & & glyoxylate oxidase \\
\hline (S) & lactate dehydrogenase (113) & & L- $\alpha$-hydroxy acid oxidase \\
\hline (L) & aspartate transaminase $(113)$ & (L) & glycolate oxidase (79) \\
\hline (C) & glutamate dehydrogenase (1 13 ) & (C) & catalase $(78,79)$ \\
\hline (L) & succinate oxidase ( 78 ) & & \\
\hline (L) & cytochrome c oxido-reductase $(78)$ & & \\
\hline (S) & phosphocholine transferase (129) & & \\
\hline
\end{tabular}

General information from references: $7,31,86,53,83,30,78,10,71,113,79,76$; studies on levels of enzyme activity are indicated in parantheses.

back again $(86,83)$. The signal for activation of the glyoxylate bypass enzymes in peroxisomes is thus likely to come from the mitochondria, in which case a structural change, as a reflection of changed function, would be expected to occur first in mitochondria and later in peroxisomes as actually observed in transition phase cells. The mutual exchange of substrate between the mitochondria and peroxisomes may require a close spatial relationship as that depicted in Figure 6; however, a 3-dimensional relationship cannot be deduced readily from a 2-dimensional plane and no connecting structure has been observed between the organelles.

The glyoxylate bypass enzymes in peroxisomes are isocitrate lyase and malate synthase (86); they are present but inactive in cells in the $\log$. phase of growth (53). Activation of the enzymes occurs even in the presence of inhibitors of RNA and protein synthesis $(68,53,71,37$, 127), which indicates that peroxisomes may change from the light to the dense type without involvement of protein synthesis. Inactivation of the enzyme is, however, dependent on protein synthesis $(70,75)$ and concomitantly the activity of an extralysosomal neutral protease increases. This protease has been proposed (75) to be involved in the modification of the peroxisomes which presumably means a change from the dense to the light type of the organelle as would occur during the lag period after inoculation of a new culture with stationary phase cells. That organelles already present are modified is likely since there is no evidence for autophagic removal of peroxisomes during conditions where they change from the dense to the light type $(89,92)$.

The activity of the mitochondrial and peroxisomal enzymes may vary during the culture cycle $(78,69,71,79,127)$. Enzymes from the two organelles in Tetrahymena are listed in Table I; for some of the enzymes it is indicated whether maximal activity is found in the log. or the stationary phase of growth, or whether their activity is constant. Apart from functioning in the glyoxylate bypass cycle, mitochondria are active in the tricarboxylate cycle (141), and peroxisomes are active in various oxidations leading to the production of hydrogen peroxide which is utilized by catalase, the marker enzyme for peroxisomes. It has been proposed (92) that the light and dense type of mitochondria represent high and low respiratory capacity of the organelle, respectively, and that the light and dense type of peroxisomes represent major activity in oxidation and in glyconeogenesis, respectively. This is in agreement with the levels of enzyme activity in the two organelles as far as information is available; future information on the maximal activity of other enzymes may reveal further evidence for this postulate. Inci- 

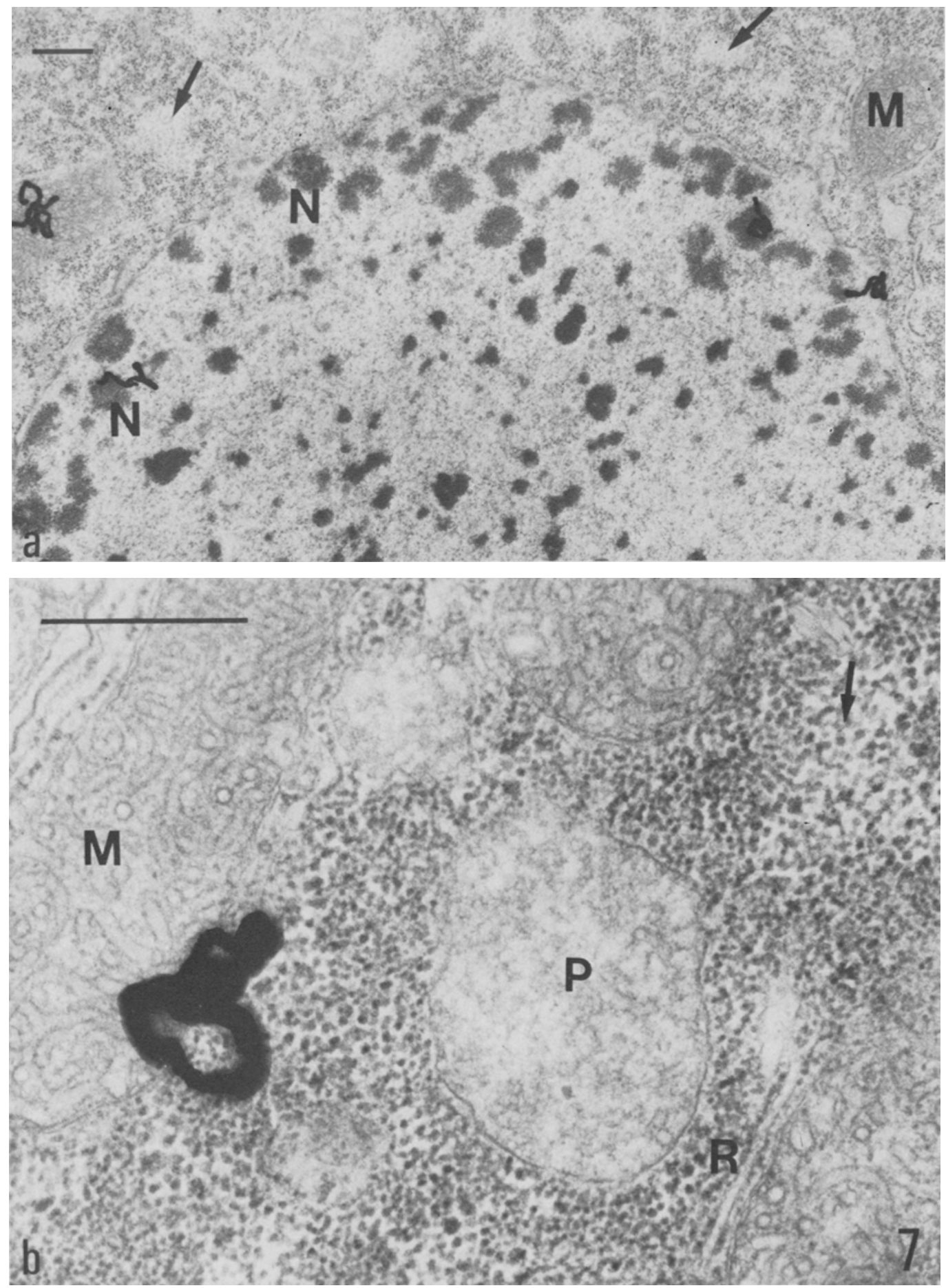

Figure $7 a-b$. Supplementation of growth medium with glucose.

Glycogen particles form islands in cytoplasm (Figure a) although other features, such as light type mitochondria and peroxisomes (Figure b), abundant ribosomes, and small nucleoli (Figure a) indicate that the cells are in the log. phase of growth. (Cell density $=80,000$ cells $/ \mathrm{ml}$; generation time $=3 \mathrm{~h}$ ). Autoradiograms of tritiated thymidine labelled cells; the curly configurations (silver grains) above mitochondria and nucleoli indicate their activity in DNA synthesis. Mitochondria (M), peroxisomes (P), glycogen particles (arrows). ribosomes $(\mathrm{R})$, nucleoli $(\mathrm{N})$. $(\mathrm{Bar}=0.5 \mu \mathrm{m})$. 
dentally, peroxisomes from stationary phase, or starved, cells have an increased median bouyant density as compared with peroxisomes from log. phase cells (78), whereas the density of mitochondria is unchanged; however, an increased electron density does not necessarily imply an increase in intrinsic mass, it may merely reflect an increased binding capacity for the heavy metals used in routine contrasting for electron microscopy.

The presence of glycogen particles in Tetrahymena grown in proteose peptone medium is usually a clear indication of activity in glyconeogenesis and of a decreased rate of cell proliferation. However, if glucose is added to the medium, although Tetrahymena does not need an extra carbon source in this medium (59), then glycogen particles are found in cells which otherwise show the typical fine structure of log. phase cells (Figure 7) and which have an unchanged generation time of $3 \mathrm{~h}$. The explanation is that excess glucose may be converted directly into glycogen $(72,57,27,113,76,127)$ and that exogenous glucose has been found to depress the activity of the glyoxylate bypass enzymes $(53,113,79)$. Thus, the presence of glycogen particles in Tetrahymena is not an unambiguous indication of a prolonged cell generation time and of activity in glyconeogenesis.

The presence of lipid droplets in Tetrahymena is invariably associated with a decreased rate of cell proliferation. The droplets appear in the early stationary phase of growth and whenever the cells are subjected to treatments that interfere with cell multiplication, as will be discussed below (section 4). The number of lipid droplets increases as the cells pass into the stationary phase but decreases late in this phase $(39,40,4$, $36,139,72,26,71,92$ ). They are generally believed to represent stores of reserve energy, a question which was investigated (12) after labelling the triacylglycerol in cells which had just ceased proliferation in the stationary phase. The labelling pattern showed a 'first in first out kinetics and $88 \%$ of the labelled triacylglycerol was turned over after $90 \mathrm{~min} ; 18 \%$ only was recovered as $\mathrm{CO}_{2} .3 \%$ as glycogen, and $76 \%$ as phospholipids (12), an indication that at this stage of growth the major part of the triacylglycerol goes into membrane synthesis. A demand for membrane synthesis at this stage may seem strange since cell proliferation has ceased; however, membrane is involved in the formation of dense granules and autophagic vacuoles. The latter organelles are prominent in starved cells (Figure 9) as will be discussed below (section 4) but they also appear in cells in the late stationary phase $(32,36,92,101)$, either as a result of partial starvation due to partial exhaustion of the medium or because worn-out orgenelles must be removed, such organelles could be mitochondria having accumulated so much calcium that their respiratory capacity is lost.

The small, dense granules also appear in cells in the stationary phase. Together with lipid droplets (Figures $5 \mathrm{~b}, 5 \mathrm{c}$ ) they represent the light microscopically visible, refractile granules (Figure 3). Analysis of isolated and in situ granules has revealed the presence of calcium, magnesium, potassium, and phosphorus in an organic matrix $(115,116,87,23)$; other ions added to the growth medium, such as strontium and lead, may also accumulate in the granules $(24,98)$. The amount of inorganic material varies in the granules $(23,24)$, as does the electron density of their contents (101), thus indicating that the granules are part of an ion-regulating system in Tetrahymena and that they act as waste disposals $(56,23,24,101)$. Since the granules appear in cells in the normal growth medium, their role in ion-regulation may be illustrated for calcium (Figure 8). A low intracellular concentration of calcium may be established in rapidly multiplying cells because there is an equilibrium between entry and output of the ion across the plasma membrane, on one side, and maintenance of a certain calcium pool and a constant flow of ions into metabolism, on the other side. When cell proliferation ceases in the stationary phase, less calcium is drawn into metabolism and excess ions enter the pathway of granule formation. assuming constancy of the other parameters; the amount of the ion accumulated and bound in the granules may correspond to $2 \mathrm{M}$-calcium (101). The limiting membrane of the dense granules resembles the plasma and food vacuolar membrane in thickness and polarity (101) as mentioned earlier, and the apparently gradual accumulation of ions in the granules could be mediated by special ATPases. Interesting in this respect is that Tetrahymena has a calcium-activated ATP- 


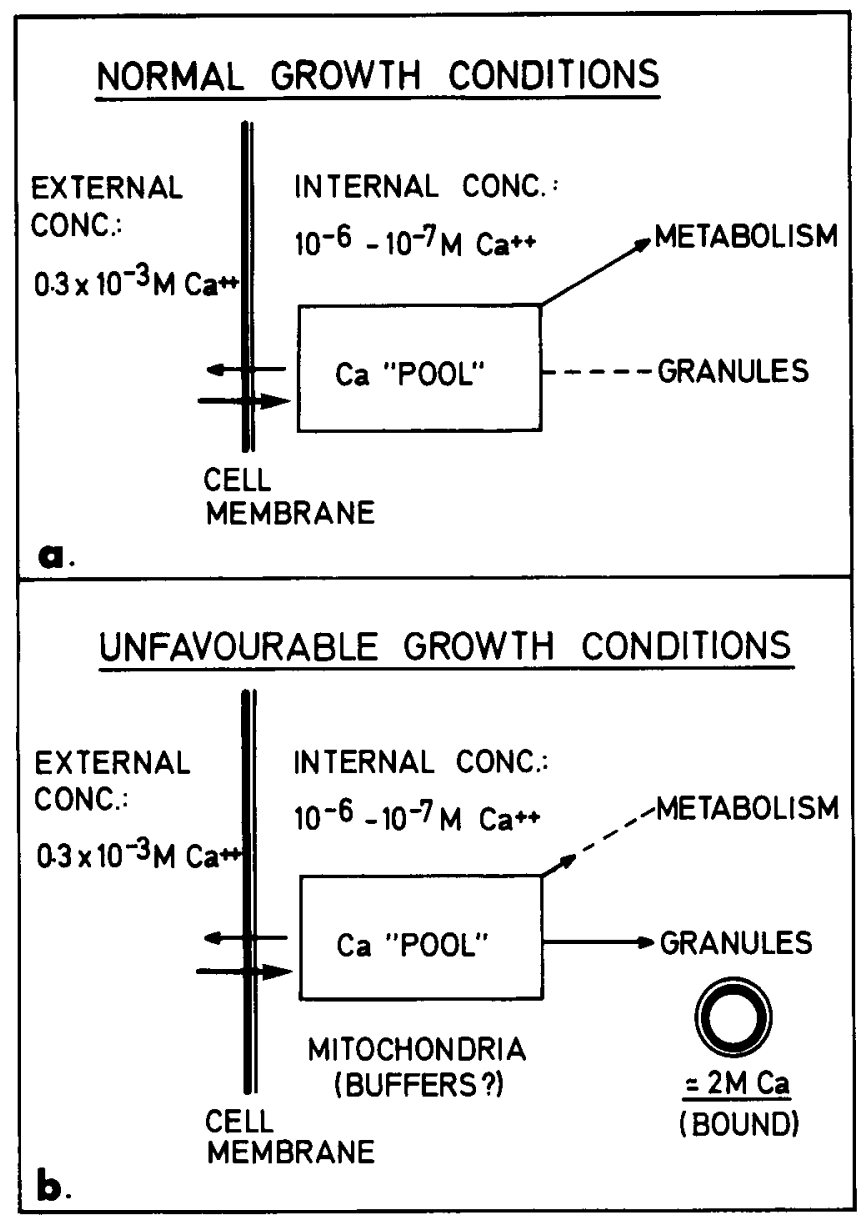

Figure 8. Model of the ion-regulating system in Tetrahymena illustrated for calcium.

To establish the low internal (cytoplasmic) concentration in a high external (medium) concentration of calcium, an efficient regulation is necessary. The model is based on the assumption of: 1) a constant influx, as well as outflux, of calcium across the cell (plasma) membrane and 2) maintenance of a compartmentalized calcium »pook and a certain flow of ions into metabolism (Figure a); this situation is valid for rapidly growing cells which do not contain refractile granules (see Figure 3). Under unfavourable conditions with decrease, or cessation, of cell proliferation less calcium is drawn into metabolism (Figure b) and the excess ions enter the pathway of granule formation for storage in a bound form. Before granule formation is activated, mitochondria may act as a buffer system in the initial removal of excess calcium. The model may be extended so as to apply to removal of other unwanted ions from the cytoplasm. Modified version of previous model (92).

ase, the activity of which increases in the stationary phase $(19,20)$ where granule formation occurs, although this ATPase was obtained from the cytosol fraction. The dense granules with their varying content of inorganic material may contaminate the mitochondria and peroxisome fractions.

The dynamic change in the population of cell organelles in Tetrahymena during the culture cycle is summarized in Table II. Not only the composition of cell constituents but also their number change in the various growth phases. Recognition of such changes is important in the preparation of cell homogenates because, dependent on the culture stage, the mitochondria and peroxisome fractions may be contaminated differently. The presence of autophagic vacuoles may be revealed by their hydrolases, whereas the detection of dense granules is more questionable. 
Table II

Changes in population of cell constituents during the culture cycle

\begin{tabular}{|c|c|c|c|c|c|}
\hline Cell constituent & Log. phase & Transition & $\begin{array}{l}\text { Early } \\
\text { stationary } \\
\text { phase }\end{array}$ & $\begin{array}{l}\text { Stationary } \\
\text { phase }\end{array}$ & $\begin{array}{l}\text { Late } \\
\text { stationary } \\
\text { phase }\end{array}$ \\
\hline Mitochondria & light type & dense type & dense type & dense type & $\begin{array}{l}\text { dense type } \\
\text { (»cores } \ll)\end{array}$ \\
\hline $\begin{array}{l}\text { Peroxisomes } \\
\text { Golgi complexes } \\
\text { Glycogen particles } \\
\text { Lipid droplets } \\
\text { Dense granules } \\
\text { Autophagic vacuoles }\end{array}$ & $\begin{array}{l}\text { light type } \\
\text { present } \\
\text { absent*) } \\
\text { absent } \\
\text { absent } \\
\text { absent }\end{array}$ & $\begin{array}{l}\text { light type } \\
\text { present } \\
\text { absent }{ }^{*} \text { ) } \\
\text { few } \\
\text { absent } \\
\text { absent }\end{array}$ & $\begin{array}{l}\text { dense type } \\
\text { present } \\
\text { present } \\
\text { many } \\
\text { present } \\
\text { absent }\end{array}$ & $\begin{array}{l}\text { dense type } \\
\text { present } \\
\text { abundant } \\
\text { abundant } \\
\text { abundant } \\
\text { few }\end{array}$ & $\begin{array}{l}\text { dense type } \\
\text { present } \\
\text { present } \\
\text { present } \\
\text { abundant } \\
\text { present }\end{array}$ \\
\hline $\begin{array}{l}\text { Nucleolar } \\
\text { organization }\end{array}$ & $\begin{array}{l}\text { numerous } \\
\text { small } \\
\text { nucleoli }\end{array}$ & $\begin{array}{l}\text { numerous } \\
\text { slightly } \\
\text { enlarged } \\
\text { nucleoli }\end{array}$ & $\begin{array}{l}\text { early } \\
\text { fusion of } \\
\text { nucleoli }\end{array}$ & $\begin{array}{l}\text { nucleolar } \\
\text { fusion } \\
\text { bodies }\end{array}$ & $\begin{array}{l}----- \\
\text { large } \\
\text { nucleolar } \\
\text { aggregates }\end{array}$ \\
\hline
\end{tabular}

*) Unless medium supplemented with glucose.

\section{RESPONSE TO VARIOUS TREATMENTS}

Structural changes are also observed in exponentially multiplying cells subjected to treatments interfering with cell proliferation. Some of the changes resemble those observed in the stationary phase of growth but others may relate to the specific action of a particular inhibitor.

Starvation is a common physiological condition which most cells experience. In Tetrahymena it can be induced abruptly by transfer of the cells to an inorganic salt medium $(47,112)$. Within $1 \mathrm{~h}$ the mitochondria and peroxisomes change to the dense type (Figure 9b) $(89,92)$ which is in agreement with a decrease in the rate of respiration to $50 \%(72)$ and $30 \%(47)$ after 1 $\mathrm{h}$ and $2 \mathrm{~h}$, respectively, and cellular activity in glyconeogenesis (71). Starvation also causes fusion of nucleoli (Figure 9a) $(72,103,92)$ and the cells contain lipid droplets, glycogen particles, small dense granules, and autophagic vacuoles $(72,89,92)$. Two types of autophagic vacuoles occur and they can be defined according to the integrity of their cytoplasmic contents, i.e. identifiable or not, the latter owing to advanced digestion (88); the former type is most frequent during early starvation. Autophagy is a mode by which the cells may sustain a basic metabolism in the absence of exogenous nutrients $(89,71$, 92) and Tetrahymena can be starved for several days at the expense of cellular RNA $(65,21,61)$ and protein $(28,68,84)$. Mitochondria, peroxisomes, and general cytoplasm (Figure 9b) may be enclosed in autophagic vacuoles $(72,88,89$, 92) during starvation. The factors determining the selection of cell components to be digested are as yet unknown; however, early during starvation mitochondria seem to be preferentially enclosed (89) causing a decrease in the number of the organelles in the central cytoplasm but apparently leaving a constant population of mitochondria in the cortical region. Typically mitochondria enclosed in autophagic vacuoles have an electron-dense core; however, this feature cannot be a general criterion for removal of the organelle because most mitochondria in starved cells may have such a dense core (92).

The inhibitor, 2,4-dinitrophenol (DNP), is an uncoupler of oxidative phosphorylation. It has a dose-dependent effect on the rate of food vacuole formation in Tetrahymena and no vacuoles are formed in $0.5 \mathrm{~mm}-\mathrm{DNP}$ (92). At this concentration the cellular rate of oxygen consumption is reduced to $30 \%$ after a 1 -h treatment $(47)$, a similar response is found for isolated mitochondria (25). After a $1-\mathrm{h}$ exposure to $0.5 \mathrm{~mm}-\mathrm{DNP}$, 

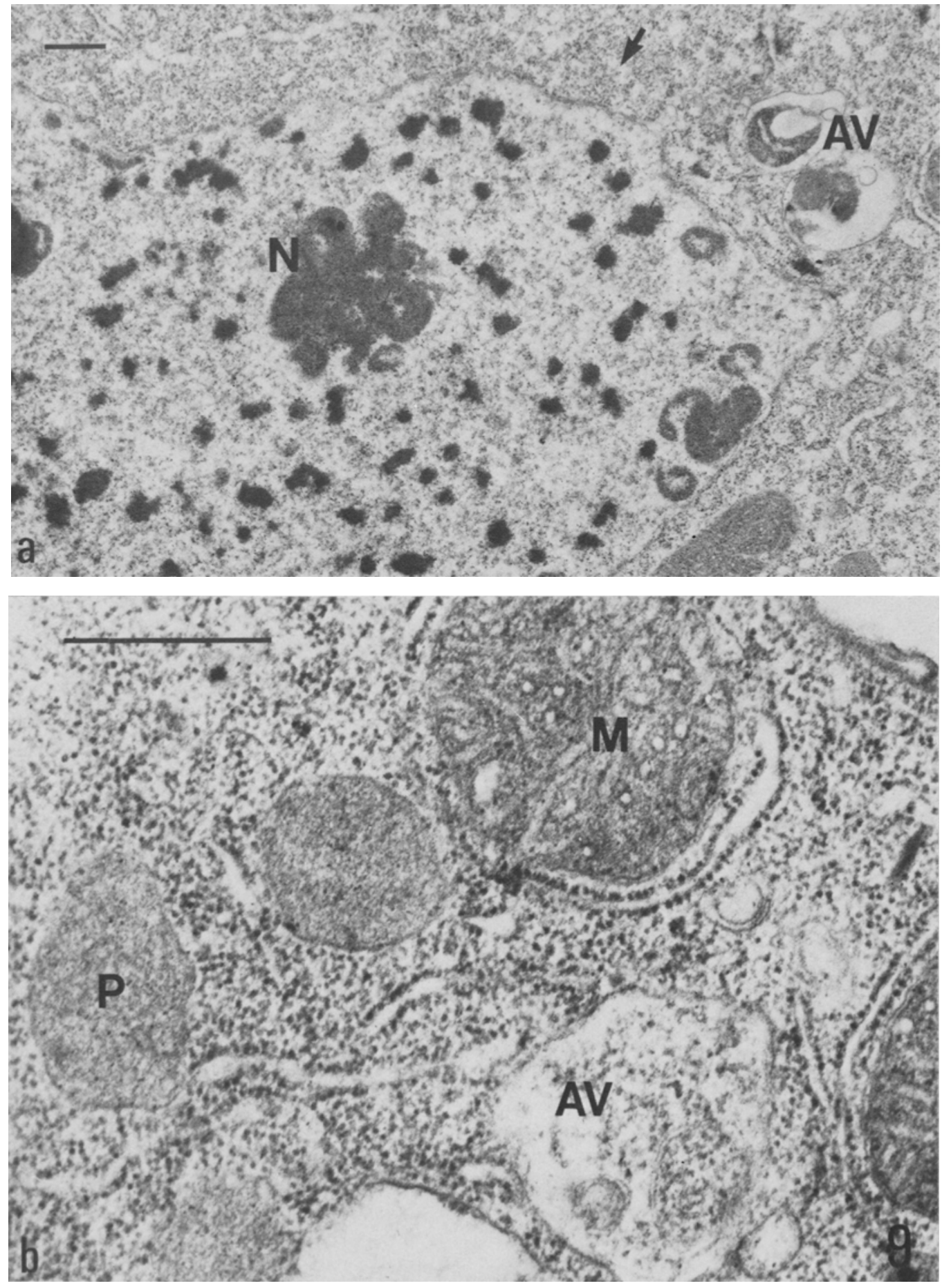

Figure $9 a-b$. The effect of starvation on Tetrahymena from the log. phase of growth.

Within $1 \mathrm{~h}$ of starvation mitochondria and peroxisomes have changed into the dense type and autophagic vacuoles are present (Figure b). Starvation causes progressive nucleolar changes and large fusion bodies are seen after $3 \mathrm{~h}$ (Figure a) at which time several autophagic vacuoles and glycogen particles (arrow) are present. Mitochondria $(M)$, peroxisomes $(P)$, autophagic vacuoles $(A V)$, nucleoli $(N) .(B a r=0.5 \mu \mathrm{m})$. 
the mitochondria appear very dense with contracted regions whereas the peroxisomes appear as an extremely light type (Figure 10a); no lipid droplets or glycogen particles are seen and the nucleoli appear »frozen« (Figure 10b), i.e. very dense and contracted (92). The cellular content of ATP is very low and cell motility has almost ceased after a 1-h treatment (unpublished results); however, the treatment is reversible although recovery is slow and involves additional and rather conspicuous changes (92).

Dimethyl sulphoxide (DMSO) is used as a solvent for water insoluble compounds or as a cryoprotective reagent. It also has a dosedependent effect on the rate of food vacuole formation in Tetrahymena $(91,92)$; cessation of vacuole formation occurs in $7.5 \%$ DMSO. After $1 \mathrm{~h}$ in this concentration, the mitochondria and peroxisomes have changed into their dense type (Figure 1la), typical of starved and stationary phase cells; furthermore, lipid droplets, glycogen particles, autophagic vacuoles, and various nucleolar changes are found $(94,95)$. Apart from the variable nucleolar changes, these effects resemble those observed during starvation; however, additional changes such as helical patterns of polyribosomes (95) and the appearance of fibrous bundles in the nucleus (99) may be ascribed to a specific action of DMSO, whereas the former effects reflect a decrease in the rates of cell proliferation (94), oxygen consumption (128), and synthesis of RNA (94) and protein (99). The cells recover from the $1-\mathrm{h}$ treatment; however, although the rate of RNA synthesis has returned to the control level $1 \mathrm{~h}$ after removal of DMSO (94), only mitochondria have reversed into the light type after $3 \mathrm{~h}$ (Figure $1 \mathrm{lb}$ ), the peroxisomes remain dense. Modification of the peroxisomes seems to be a slow process.

Cytochalasin B (CCB) interferes with microfilaments. This inhibitor also has a dose-dependent effect on food vacuole formation in Tetrahymena $(107,52,114)$ and phagocytosis is completely inhibited in $40 \mu \mathrm{g} \cdot \mathrm{ml}^{-1}$. However, at this concentration both mitochondria and peroxisomes remain of the light type $(92,96)$. The rate of cell proliferation is somewhat affected, as also reflected by slightly enlarged nucleoli and a slightly reduced rate of RNA synthesis (96). Although phagocytosis is inhibited in CCB the cells show considerable uptake of compounds normally internalized by phagotrophy (114). These apparently conflicting findings may be explained by the presence of a new type of small vacuoles in CCB-treated cells (96); such vacuoles are not found in untreated cells and they may represent pinocytic vacuoles formed in the oral region. Thus, inhibition of food vacuole formation may not necessarily imply starvation and concomitant changes in the structure of mitochondria and peroxisomes. The small digestive vacuoles, formed in the presence of $\mathrm{CCB}$, may sediment with mitochondria and peroxisomes in cell fractionations.

Addition of $0.8 \%$ glycerol to the growth medium has a slight effect on the rate of cell proliferation without causing marked structural changes. However, in the early stationary phase mitochondria change into the dense whereas the peroxisomes appear as an extremely light type (Figure 12), although the nucleoli show advanced changes (compare Figures $12 \mathrm{a}$ and $4 \mathrm{c}$ ). Furthermore, glycogen particles are present which is not in agreement with the structure of peroxisomes; however, glycerol may enter the pyruvate to glucose pathway and be converted into glycogen without involvement of the glyoxylate bypass $(9,113,76)$ which explains the apparent discrepancy in these experiments.

Heat synchronization of cell divisions in Tetrahymena $(125,148)$ involves a series of temporal elevation of the growth temperature to a sublethal level $\left(34^{\circ} \mathrm{C}\right)$. This $\gg$ multi-heat shock « treatment (148) of log. phase cultures initially causes an arrest of cell division but not of cell growth (148) in the asynchronous culture and at the end of the treatment the cells divide with a high degree of synchrony; this technique has been used extensively for studies of cell cycle events $(82,148)$. In synchronized cells, the mitochondria and peroxisomes are both of the dense type (92) in agreement with a decreased rate of oxygen consumption (48) and activity in glyconeogenesis $(124,71)$; the latter function is also indicated by the presence of glycogen particles in the cells (92). The nucleoli are somewhat enlarged (104) in accordance with a decreased rate of RNA synthesis $(8,148,146)$; incidentally, gross nucleolar changes are seen when cultures of high cell density are subjected to the heat synchronization technique (35). When the »one heat shock per generation« 

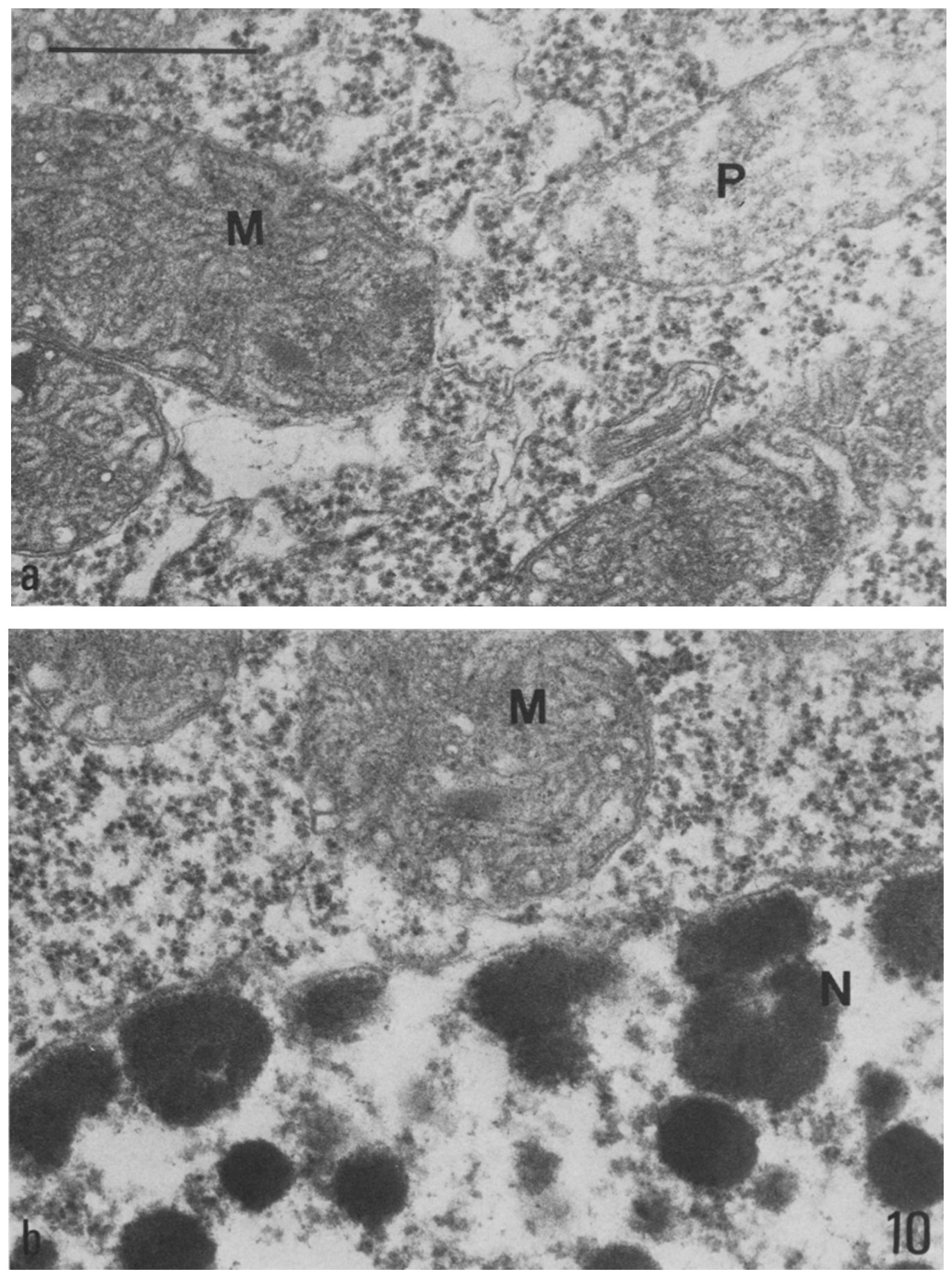

Figure $10 \mathrm{a}-\mathrm{c}$. The effect of a $1-\mathrm{h}$ exposure to $0.5 \mathrm{~mm}-2,4-\mathrm{dinitrophenol}$ of Tetrahymena from log. phase cultures.

The mitochondria are extremely dense with »contracted« regions (both figures) and the peroxisomes are an extremely light type (Figure a); the nucleoli are very dense and appear ifrozen« (Figure b). For structural changes during recovery from the treatment see $(92)$ from which these figures are reproduced. Mitochondria (M), peroxisome $(\mathrm{P})$, nucleoli $(\mathrm{N})$. $(\mathrm{Bar}=0.5 \mu \mathrm{m})$. 

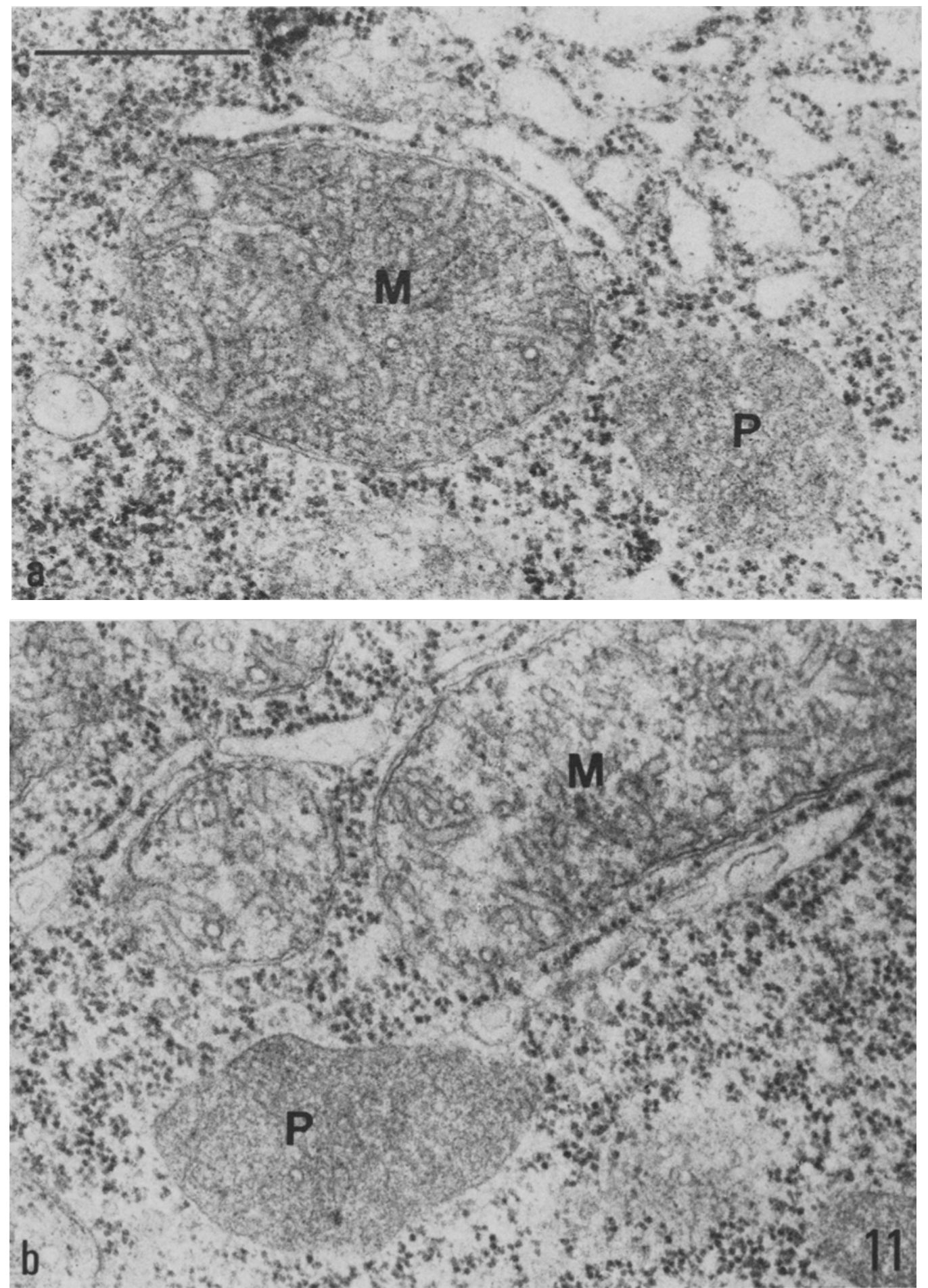

Figure $1 \mathrm{la}-\mathrm{b}$. Effect of a $1-\mathrm{h}$ exposure to $7.5 \%$ dimethyl sulphoxide of Tetrahymena from log. phase cultures.

The mitochondria and peroxisomes have changed into the dense type (Figure a). Recovery from the treatment is slow and $3 \mathrm{~h}$ after removal of the reagent, the mitochondria have changed into the light type, whereas the peroxisomes are still of the dense type (Figure b). Mitochondria $(\mathrm{M})$, peroxisomes $(\mathrm{P})$. (Bar $=0.5 \mu \mathrm{m})$. 

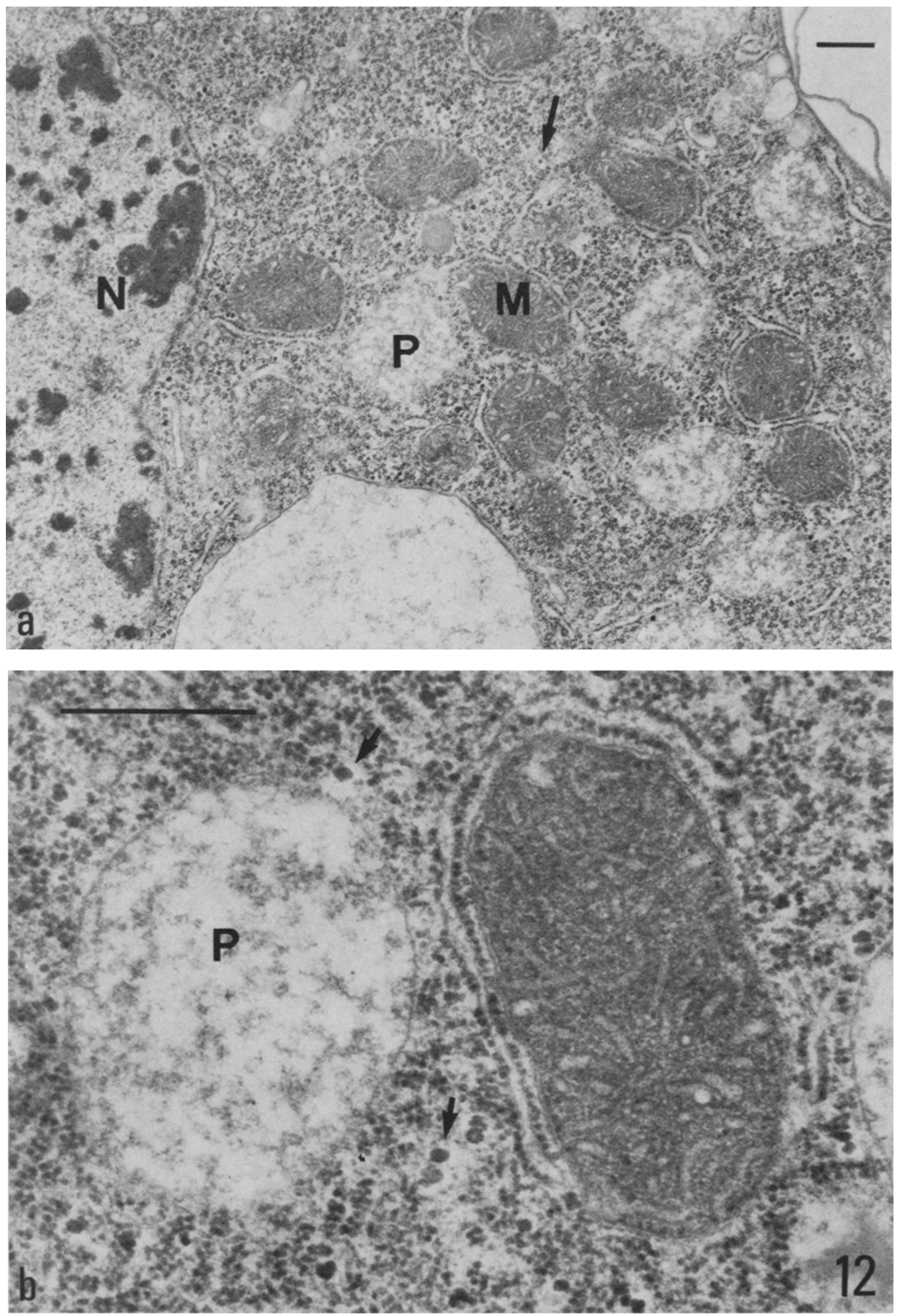
Figure 12a-b. Addition for $5 \mathrm{~h}$ of glycerol $(0.8 \%)$ to the growth medium.

In the log. phase of growth little structural change is observed (slightly prolonged generation time); however, here in the early stationary phase of growth, as also indicated by the nucleolar changes (Figure a; compare with Figure $4 \mathrm{c}$ ), the mitochondria are dense but the peroxisomes are extremely light in structure (Figure $\mathrm{b}$ ) and glycogen particles (arrows) are present. Mitochondria (M), peroxisomes (P), nucleoli (N).

$($ Bar $=0.5 \mu \mathrm{m})$.

method (147) is used to synchronize the cells, mitochondria and peroxisomes remain unchanged (106) and no nucleolar changes are observed (105). During heat synchronization the cells are exposed to the sublethal temperature for 20-30 min (148) spaced with intervals at the normal growth temperature; however, if the cells are exposed continuously to the high temperature different structural changes are observed $(74,92)$. Thus, after a 3 -h treatment, the mitochondria of the dense type appear with enlarged tubuli (92) and the peroxisomes appear as an extremely light type $(74,92)$; in addition, autophagic vacuoles and large nucleolar fusion bodies are seen $(74,92)$. Macromolecular synthesis is largely inhibited in these cells (148).

The relationship between the structure of mitochondria and peroxisomes in Tetrahymena is summerized in Table III. In most instances the organelles appear as the corresponding type, either light or dense, in agreement with the rate of cellular respiration and activity in glyconeoge- nesis as discussed in the individual cases. When this correlation is not seen, plausible explanations for finding the peroxisomes in the light type have been presented; however, in the case of the DNP-treated cells, and cells exposed to sublethal temperature, the situation seems more obscure. The extremely light peroxisomes may have an increased rate of oxidation, i.e. they take over as respiratory organelles (30), in order to protect the cells against oxygen toxicity during treatments which affect grossly the mitochondrial activity (92).

\section{CONCLUDING REMARKS}

An attempt has been made to illustrate that the physiological state of Tetrahymena is reflected in the overall fine structure of the cells. The present review elucidates the dynamic changes which the population of cell organelles undergoes during the different phases of the culture cycle and in response to various treatments of

\section{Table III}

Interrelationship of structural types of mitochondria and peroxisomes

\begin{tabular}{lccc}
\hline Condition & Mitochondria & Peroxisomes & Reference \\
\hline Logarithmic phase (control) & light & light & $(89,92)$ \\
Transition stage & dense & light & $(92)$ \\
Stationary phase & dense & dense & $(89,92)$ \\
Starvation $(1 \mathrm{~h})$ & dense & dense & $(92)$ \\
$0.5 \mathrm{~mm}-\mathrm{DNP}(1 \mathrm{~h})$ & extremely dense & extremely light & $(92,95)$ \\
$7.5 \% \mathrm{DMSO}(\mathrm{h})$ & dense & dense & $(92,96)$ \\
$40 \mu \mathrm{CCB} / \mathrm{ml}(\mathrm{l} \mathrm{h})$ & light & light & \\
$0.8 \%$ glycerol $(5 \mathrm{~h})$ & dense & extremely light & $(92)$ \\
(early stationary phase) & & dense & $(106)$ \\
Heat synchronization 1. & dense & light & $(74,92)$ \\
Heat synchronization 2. & light & extremely light & \\
Sublethal temperature $(3 \mathrm{~h})$ & dense with & & \\
& enlarged tubuli & & \\
\hline
\end{tabular}

DNP $=2,4$ dinitrophenol; DMSO = dimethyl sulphoxide; $\mathrm{CCB}=$ cytochalasin $\mathrm{B}$;

heat synchronization: $1 .=$ multi-heat shocks $(125)$ and $2 .=» 1$ shock per generation $(147)$. 
rapidly growing cells. Moreover, evidence has been presented for the proposal that the fine structure of mitochondria and peroxisomes reflects the energized state of the organelles. Indirect support from other investigators for this proposal is given by the observations that on exposure of Tetrahymena to phenol, which reduces the rate of oxygen consumption, the mitochondria change into a more dense form (126), and that the giant peroxisomes in chemostatically grown cells with a high rate of glyconeogenesis, are dense in structure (62). Although the overall impression may be that the observed fine structure of the cell organelles seems to reflect their functional state, much more research is needed on the subject before this relationship is fully understood.

\section{ACKNOWLEDGEMENTS}

My sincere thanks to Dr. MiKLos MülleR for asking me to review this topic in the Symposium on Cell Organelles held during the VI International Congress on Protozoology in Warsaw, July 1981. Furthermore, I am most grateful to the Editors of Carlsberg Research Communications for publishing this review on the grounds that much of the basic work was carried out during the 10 years I worked at the Biological Institute of the Carlsberg Foundation. The continued support of the Carlsberg Foundation is gratefully acknowledged. Dr. Cicily Chapman-ANDresen and Professor Christian Overgaard Nielsen are thanked for critical reading of the manuscript.

\section{REFERENCES}

1. Alexander, J. B.: The mucocysts of Tetrahymena pyriformis: Localization of the TCAethanol-soluble protein. Exp. Cell Res. 49, 425-440 (1968)

2. Allen, N. E. \& Y. Suyama: Protein synthesis in vitro with Tetrahymena mitochondrial ribosomes. Biochem. Biophys. Acta 259, 369-377 (1972)

3. Allen, R. D.: Fine structure, reconstruction and possible functions of components of the cortex of Tetrahymena pyriformis. J. Protozool. 14, 553-565 (1967)

4. Allison, B. M. \& R. R. Ronkin: Lipid cytochemistry and morphologic change in aging populations of Tetrahymena. J. Protozool. 14 313-319 (1967)

5. Barber, A. A., W. W. Harris \& G. M. Padilla: Studies of native glycogen isolated from synchronized Tetrahymena pyriformis (HSM). J. Cell Biol. 27, 281-292 (1965)

6. Baudhuin, P. \& M. Müller: Unpublished results (1967) cited in Müller, M. (1969)

7. Baudhuin, P., M. Müller, B. Poole \& C. DE Duve: Non-mitochondrial oxidizing particles (microbodies) in rat liver and kidney and in Tetrahymena pyriformis. Biochem. Biophys. Res. Commun. 20, 53-59 (1965)

8. Bernstein, E. \& E. Zeuthen: The relationship of RNA synthesis to temperature as an inducer of synchronous division. C. R. Trav. Lab Carlsberg 35, 501-517 (1966)

9. Blum, J. J.: Effect of AMP and related compounds on glycogen content of Tetrahymena. J. Cell Physiol. 80, 443-452 (1972)

10. BLuM, J. J.: Localization of some enzy mes of $\beta$ oxidation of fatty acids in the peroxisomes of Tetrahymena. J. Protozool. 20, 688-692 (1973)

11. Borden, D., G. S. Whitt \& D. L. Nanney: Electrophoretical characterization of classical Tetrahymena pyriformis strains. J. Protozool. 20, 693-700 (1973)

12. Borowitz, M. J. \& J. J. Blum: Triacylglycerol turnover in Tetrahymena pyriformis. Relation to phospholipid synthesis. Biochim. Biophys. Acta 424, 114-124 (1976)

13. Borst, P.: Mitochondrial nucleic acids of protozoa. in: Biochemistry and Physiology of Protozoa, 2nd ed. M. Levandowsky \& S. H. Hutner eds., Academic Press, New York, Vol. III pp. 341-364 (1980)

14. Brunk, C. F. \& P. C. Hanawalt: Mitochondrial DNA in Tetrahymena pyriformis. Exp. Cell Res. 54, 143-149 (1969)

15. Cameron, I. L. \& E. E. Guile: Nucleolar and biochemical changes during unbalanced growth of Tetrahymena pyriformis. J. Cell Biol. 26, 845-855 (1965)

16. Charret, R.: Modifications des mitochondries et synthèse de l'ADN mitochondrial de Tetrahymena pyriformis après action du bromure d'éthidium. J. Microscopie 14, 279-296 (1972)

17. Charret, R. \& J. AndrÉ: La synthèse de I'ADN mitochondrial chez Tetrahymena pyriformis. Etude radioautographique quantitative au microscope électronique, J. Cell Biol. 39 , 369-381 (1968)

18. Charret, R. \& M. Charlier: Visualisation de la transcription et de la traduction dans les 
mitochondries de Tetrahymena pyriformis. $J$. Microscopie 17, 19-26 (1973)

19. Chua, B., C. Elson \& E. Shrago: Identification and purification of a soluble adenosine triphosphatase from Tetrahymena pyriformis. Biochem. Biophys. Res. Commun. 69, 641647 (1976)

20. Chua, B., C. Euson \& E. Shrago: Purification and properties of a cytosol $\mathrm{Ca}^{2}$-activated ATPase from Tetrahymena pyriformis. J. Biol. Chem. 252, 7548-7554 (1977)

21. Cline, S. G. \& R. L. Conner: Ortophosphate excretion as related to RNA metabolism in Tetrahymena. J. Cell Physiol. 68, 149-156 (1966)

22. Coleman, J. R., G. Kimmick \& J. R. Nilsson: unpublished results (1971) cited in (92)

23. Coleman, J. R., J. R. Nilsson, R. R. Warner $\&$ P. BATT: Qualitative and quantitative electron probe analysis of cytoplasmic granules in Tetrahymena pyriformis. Exp. Cell Res. 74, 207-219(1972)

24. Coleman, J. R., J. R. NiIsson, R. R. Warner \& P. BATT: Effects of calcium and strontium on divalent ion content of refractive granules in Tetrahymena pyriformis. Exp. Cell Res. 80, 19 (1973)

25. Conkuin, K. A. \& S. C. Chou: Isolation and characterization of Tetrahymena pyriformis GL mitochondria. Comp. Biochem. Physiol. $41 \mathrm{~B}, 45-54$ (1972)

26. Connett, R. J. \& J. J. Blum: Metabolic pathways in Tetrahymena. Estimation of rates of the tricarboxylic acid cycle, glyoxylate cycle, lipid synthesis, and related pathways by use of multiple labelled substrates. J. Biol. Chem. 247, 5199-5209 (1972)

27. Connett, R. J., B. Wittels \& J. J. Blum: II. Compartmentalization of acetyl coenzyme A and structure of the glycolytic and gluconeogenic pathways. J. Biol. Chem. 247, 2657-2661 (1972)

28. Crockett, R. L., P. B. Dunham \& L. Rasmussen: Protein metabolism in Tetrahy. mena pyriformis cells dividing synchronously under starvation conditions. C. R. Trav. Lab. Carlsberg 34, 451-486 (1965)

29. DANFORTH, W. F.: Respiratory metabolism. in: Research in Protozoology, T.-T. Chen ed., Pergamon Press, Oxford-New York-Toronto, Vol. I pp. 201-306 (1967)

30. DE DUVE, C.: The peroxisome: A new cytoplasmic organelle. Proc. Roy. Soc. B 173, 71-83 (1969)

31. De Duve, C. \& P. Baudhuin: Peroxisomes (mi- crobodies) and related particles. Physiol. Rev. 46, 323-357 (1966)

32. ElLjott, A. M. \& I. J. BaK: The fate of mitochondria during aging in Tetrahymena pyriformis. J. Cell Biol. 20, 113-129 (1964)

33. Elliott, A. M. \& J. R. KenNedy: Morphology of Tetrahymena. in: Biology of Tetrahymena, A. M. Eluotot ed., Dowden, Hutchinson \& Ross Inc., Stroudsburg Pa., pp 57-87 (1973)

34. Elliott, A. M. \& R. G. ZieG: A golgi apparatus associated with mating in Tetrahymena pyriformis. J. Cell Biol. 36, 391-398 (1968)

35. Elliott, A. M., J. R. Kennedy \& I. J. BaK: Macronuclear events in synchronously dividing Tetrahymena pyriformis. J. Cell Biol. 12, 515531 (1962)

36. Elliott, A. M., D. M. Travis \& J. A. Work: An Ultrastructural study of the effects of aeration and physical activity on aging in Tetrahymena pyriformis. J. Exp. Zool. 161, $177-192(1966)$

37. Elson, C., E. Shrago, E. Sondheimer \& M. YATVIN: Acceleration of gluconeogenesis following inhibition of protein synthesis in Tetrahymena pyriformis. Biochim. Biophys. Acta 297, 125-134 (1973)

38. Engberg, J., J. R. Nilsson, R. E. Pearlman \& V. LEICK: Induction of nucleolar and mitochondrial DNA replication in Tetrahymena pyriformis. Proc. Nat. Acad. Sci. U.S.A. 71, 894-898 (1974)

39. ERwIN, J, A. \& K. BLoCh: Lipid metabolism of ciliated protozoa. J. Biol. Chem. 238, 16181624 (1963)

40. Everhardt, L. P. \& R. R. Ronkin: Changes in the lipids of cell from aging populations of Tetrahymena pyriformis. J. Protozool. 13, 646-650 (1966)

41. Flavell, R. A. \& I. G. Jones: Mitochondrial deoxyribonucleic acid from Tetrahymena pyriformis and its kinetic complexity. Biochem. J. $116,811-817(1970)$

42. Flickinger, C. J. \& R. L. Murray: Cytoplasmic membrane changes in conjugating Tetrahymena. Cell Tiss. Res. 153, 357-364 (1974)

43. Franke, W. W. \& W. A. Eckert: Cytomembrane differentiation in a ciliate, Tetrahymena pyriformis. II. Bifacial cisternae and tubular formations. Z. Zellforsch. 122, 244-253 (1971)

44. Franke, W. W. \& J. Kartenbeck: Some principles of membrane differentiation. in: Progress in Differentiation Research, N. MüLLer-Berat, C. Rosenfeld, D. Tarin \& D. Viza 
eds., North-Holland Publ., Amsterdan, pp 213-243 (1976)

45. Franke, W. W., W. A. Eckert \& S. Krien: Cytomembrane differentiation in a ciliate. Tetrahymena pyriformis. I. Endoplasmic reticulum and dictyosomal equivalents. Z. Zellforsch. 119, 577-604 (1971)

46. Gurgy, J.-J.. G. Ledoigt, B. J. Stevens \& J. ANDRÉ: Mitochondrial and cytoplasmic ribosomes from Tetrahymena pyriformis. Correlative analysis by gel electrophoresis and electron microscopy. J. Cell Biol. 60. 628-640 (1974)

47. Hamburger, K. \& E. Zeuthen: Synchronous divisions in Tetrahymena pyriformis as studied in an inorganic medium. The effect of 2,4 dinitrophenol. Exp. Cell Res. 13, 443-453 (1957)

48. Hamburger, K. \& E. Zeuthen: Some characteristics of growth in normal and synchronized populations of Tetrahymena pyriformis. C. R. Trav. Lab. Carlsberg 32, 1-18 (1960)

49. Hamburger, K. \& E. Zeuthen: Respiratory responses to dissolved food of starved, normal and division-synchronized Tetrahymena cells. C. R. Trav. Lab. Carlsberg 38, 145-161 (1971)

50. Hayashi, M.: Temperature, chemicals and enzyme effects on the structure of discharged mucocysts from Tetrahymena pyriformis. Cytobiologie 9, 460-468 (1974)

51. Hino, Y., S. Minakami \& H. Murakami: The comparison of Golgi subfractions isolated from mitochondrial fraction with those from microsomal fraction. Exp. Cell Res. 133, 171-179 (1981)

52. Hoffmann, E. K., L. Rasmussen \& E. ZeuTHEN: Cytochalasin B: Aspects of phagocytosis in nutrient uptake in Tetrahymena. J. Cell Sci. 15, 403-406 (1974)

53. HogG, J. F.: Peroxisomes in unicellular organisms. Peroxisomes in Tetrahymena and their relation to gluconeogenesis. Ann. N. Y. Acad. Sci. 168, 281-291 (1969)

54. Hogg, J. F. \& H. L. Korngerg: The metabolism of $\mathrm{C}_{2}$-compounds in microorganisms. a. Role of the glyoxylate cycle in protozoal glyconeogenesis. Biochem. J. 86, 462-468 (1963)

55. Hull, R. W. \& J. E. Morrissey: Metabolic efficiency of Tetrahymena pyriformis, strain $\mathrm{WL}$, as related to culture age. Trans. Amer. Microsc. Soc. 79, 127-135 (1960)

56. JONES, A. R.: Mitochondria, calcification and waste disposal. Calc. Tiss. Res. 3, 363-365 (1969)

57. KaHN, V. \& J. J. Blum: Interaction between glycogen and glycogen phosphorylase of Tetrahymena. Arch. Biochem. Biophys. 145, 382391 (1971)

58. Kay, E., K. Rohatgi \& S. Krawieg: Morphometric studies of mitochondria in Tetrahymena pyriformis exposed to chloroamphenicol or ethidium bromide. J. Protozool. 21, 608-612 (1974)

59. Kidder, G. W. \& V. C. Dewey: The biochemistry of ciliates in pure culture. in: Biochemistry and Physiology of Protozoa. A. Lwoff ed. Academic Press, New York, Vol. I pp. 323400 (1951)

60. Kolb-Bachofen, V.\& W. Vogell: Mitochondrial proliferation in synchronized cells of Tetrahymena pyriformis. A morphometric study by electron microscopy on the biogenesis of mitochondria during the cell cycle. Exp. Cell Res. 94, 95-105 (1975)

61. Koroly, M. J. \& R. L. Conner: The fate of RNA degradation products in starved cultures of Tetrahymena pyriformis W. J. Protozool. 21, 169-177 (1974)

62. Larned, R. W. \& G. A. Antipa: Giant peroxisomes in chemostatically grown Tetrahymena. Progress in Protozoology, V. Intern. Congr. Protozoology, New York 1977, abstract 111 (1977)

63. Lazarow, P. B. \& C. De Duve: The synthesis and turnover of rat liver peroxisomes. IV. Biochemical pathway of catalase synthesis. J. Cell Biol. 59, 491-506 (1973)

64. Lazarow, P. B. \& C. De Duve: The synthesis and turnover of rat liver peroxisomes. V. Intracellular pathway of catalase synthesis. $\mathbf{J}$. Cell Biol 59, 507-524 (1973)

65. Leboy, P. S., S. G. Cuine \& R. L. Conner: Phosphate, purines and pyrimidines as excretory products of Tetrahymena. J. Protozool. $11,217-222(1964)$

66. LEICK, V.: The formation of ribosomes in Tetrahymena pyriformis. Tutein and Koch, Copenhagen (1973)

67. Leick, V, T. Tennesen, J. Engberg \& J. R. Nitsson: Nucleolar reorganization in Tetrahymena pyriformis GL during a nutritional shiftup; timing of ribosomal RNA transcription and ribosomal DNA replication. in: Proceedings 9. Congress Nordic Society for Cell Biology, F. Bierring ed., Odense University Press, pp. 205-211 (1976)

68. LEVY, M. R.: Effects of inhibitors of RNA and protein synthesis on activation of glyconeogenesis in Tetrahymena. J. Cell. Physiol. 69. 247252 (1967) 
69. Levy, M. R.: Regulation of isocitrate metabolism in peroxisomes in Tetrahymena pyriformis. Arch. Biochem. Biophys. 152, 463-471 (1972)

70. LeVY, M. R.: Decrease of peroxisomal enzymes in Tetrahymena and its prevention by actinomycin D and cycloheximid. Biochim. Biophys. Acta 304, 367-374 (1973)

71. LeVY, M. R.: Effects of some environmental factors on the biochemistry, physiology, and metabolism of Tetrahymena. in: Biology of Tetrahymena, A. M. Elliort ed., Dowden, Hutchinson \& Ross, Stroudsburg Pa., pp. 227257 (1973)

72. Levy, M. R. \& A. M. Elulotr: Biochemical and ultrastructural changes in Tetrahymena pyriformis during starvation. J. Protozool. 15, 208-222 (1968)

73. Levy, M. R. \& O. H. Scherbaum: Glyconeogenesis in growing and non-growing cultures of Tetrahymena pyriformis. J. Gen. Microbiol. 38, 221-230 (1965)

74. Levy, M. R., C. E. Gollon \& A. M. Ellott: Effects of hyperthermia on Tetrahymena. 1. Localization of acid hydrolases and changes in cell ultrastructure. Exp. Cell Res. 55, 295-305 (1969)

75. Levy, M. R., E. E. Sisskin \& C. L. McConkey: A protease that increases during a period of enzymic and metabolic adjustment in Tetrahymena. Arch. Biochem. Biophys. 172, 634647 (1976)

76. Liang, T., G. J. Raugi \& J. J. Blum: Effect of 4-pentenoic acid on intermediate metabolism of Tetrahymena. J. Protozool. 23, 186-193 (1976)

77. LLOYD, D.: The Mitochondria of Microorganisms. Academic Press, London-New York-San Francisco (1974)

78. Lloyd, D., R. Brightwell, S. E. Venables, G. I. RoACH \& G. TURNer: Subcellular fractionation of Tetrahymena pyriformis ST by zonal centrifigation: Changes in activities and distribution of enzymes during the growth cycle and on starvation. J. Gen. Microbiol. 65, 209-223 (1971)

79. LORD, J. M., B. A. MCFadden \& H. L. KORNBERG: Changes in microbody-marker enzymes during growth of Tetrahymena pyriformis $E$. Proc. R. Soc. Lond. B 185, 19-31 (1974)

80. Manners, D. J. \& J. F. Ryley: Studies on the metabolism of the protozoa. 2. The glycogen of the ciliate Tetrahymena pyriformis (Glaucoma piriformis). Biochem. J. 52, 480-482 (1952)

81. Meyer, R. R., C. R. Boyd, D. C. Rein \& S. J. KELLER: Effects of ethidium bromide on growth and morphology of Tetrahymena pyriformis. Exp. Cell Res. 70, 233-237 (1972)

82. Mitchison, J. M.: The Biology of the Cell Cycle. University Press Cambridge (1971)

83. Müller, M.: Peroxisomes of protozoa. Ann. N.Y. Acad. Sci. 168, 292-301 (1969)

84. Müller, M.: Secretion of acid hydrolases and its intracellular source in Tetrahymena pyriformis. J. Cell Biol. 52, 478-487 (1972)

85. MülLER, M.: Biochemistry of protozoan microbodies: peroxisomes, $\alpha$-glycerophosphate oxidase bodies, hydrogenosomes. Ann. Rev. Microbiol. 29, 467-483 (1975)

86. Müller, M., J. F. Hogg \& C. De Duve: Distribution of tricarboxylic acid cycle enzymes and of glyoxylate cycle enzymes between mitochondria and peroxisomes in Tetrahymena pyriformis. J. Biol. Chem. 243, 5385-5395 (1968)

87. Munk, N. \& H. Rosenaerg: On the deposition and utilization of inorganic pyrophosphate in Tetrahymena pyriformis. Biochim. Biophys. Acta 177, 629-640 (1969)

88. Nilsson, J. R.: Cytolysomes in Tetrahymena pyriformis GL. I. Synchronized cells dividing in inorganic salt medium. C. R. Trav. Lab. Carlsberg 38, 87-106 (1970)

89. Nilsson, J. R.: Cytolysomes in Tetrahymena pyriformis GL. II. Reversible degeneration. C. R. Trav. Lab. Carlsberg 38, 107-121 (1970)

90. Nilsson, J. R.: Further studies on vacuole formation in Tetrahymena pyriformis GL. C. R. Trav. Lab. Carlsberg 39, 83-110 (1972)

91. Nilsson, J. R.: Effects of DMSO on vacuole formation, contractile vacuole function, and nuclear division in Tetrahymena pyriformis GL. J. Cell Sci. 16, 39-47 (1974)

92. Nitsson, J. R.: Physiological and structural studies on Tetrahymena pyriformis GL. With special reference to endocytosis and to structural changes during the cell cycle and in response to alterations in the cellular environment. C. R. Trav. Lab. Carlsberg 40, 215-355 (1976)

93. Nilsson, J. R : On structural nucleolar changes in Tetrahymena pyriformis GL. in: Proceedings 9. Congress Nordic Society for Cell Biology, F. Bierring ed., Odense University Press, pp. 197203 (1976)

94. Nilsson, J. R.: Reversible inhibition of RNA synthesis in Tetrahymena pyriformis GL by dimethyl sulphoxide: An electron microscope autoradiographic study. Trans. Amer. Microsc. Soc. 95, 403-414 (1976)

95. Nilsson, J. R.: Effects of dimethyl sulfoxide on Tetrahymena pyriformis GL. Fine structural 
changes and their reversibility. J. Protozool. 24 , 275-283 (1977)

96. NiLsson, J. R.: Fine structure and RNA synthesis of Tetrahymena during cytochalsin $B$ inhibition of phagocytosis. J. Cell Sci. 27, 115126 (1977)

97. NiLsson, J. R.: Phagotrophy in Tetrahymena. in: Biochemistry and Physiology of Protozoa, 2nd ed. M. Levandowsky \& S. H. Hutner eds., Academic Press, New York, Vol. I pp. 339-379 (1979)

98. NiLsson, J. R.: Intracellular distribution of lead in Tetrahymena during continuous exposure to the metal. J. Cell Sci. 39, 383-396 (1979)

99. NiLsson, J. R.: Effects of dimethyl sulphoxide on ATP content and protein synthesis in Tetrahymena. Protoplasma 103, 189-200 (1980)

100. Nilsson, J. R. \& O. Behnke: Studies on a surface coat of Tetrahymena pyriformis GL. J. Ultrastr. Res. 36, 542-545 (1971)

101. Nilsson, J. R. \& J. R. Coleman: Calcium-rich, refractile granules in Tetrahymena pyriformis and their possible role in the intracellular ionregulation. J. Cell Sci. 24, 311-325 (1977)

102. Nilsson, J. R. \& A. Forer: Cyclic appearance and disappearance of cytoplasmic granules in Tetrahymena pyriformis GL. J. Protozool. 19, Suppl. pp 41 (1972)

103. NiLsSON, J. R. \& V. Leick: Nucleolar organization and ribosome formation in Tetrahymena pyriformis GL. Exp. Cell Res. 60, 361-372 (1970)

104. Nilsson, J. R. \& E. Zeuthen: Microscopical studies on the macronucleus of heat synchronized Tetrahymena pyriformis GL. C. R. Trav. Lab. Carlsberg 40, 1-18 (1974)

105. Nilsson, J. R. \& E. Zeuthen: On nucleolar DNA replication in Tetrahymena pyriformis GL-8: An electron microscope autoradiographic study of heat synchronized and exponentially multiplying cells. Carlsberg Res. Commun. 45, 101-111 (1980)

106. Nilsson, J. R. \& E. Zeuthen: unpublished results

107. Nilsson, J. R., T. R. Ricketts \& E. Zeuthen: Effects of cytochalasin $B$ on cell division and vacuole formation in Tetrahymena pyriformis GL. Exp. Cell Res. 79, 456-459 (1973)

108. Novikoff, P. M., A. B. Novikoff, N. Quintana \& C. Davis: Studies on microperoxisomes. III. Observations on human and rat hepatocytes. J. Histochem. Cytochem. 21, 540558 (1973)

109. OrmsBeE, R. A.: The normal growth and respiration of Tetrahymena geleii. Biol. Bull. 82, 423-437 (1942)

110. Parsons, J. A.: Mitochondrial incorporation of tritiated thymidine in Tetrahymena pyriformis.

J. Cell Biol, 25. 641-646 (1965)

111. Parsons, J. A. \& R. C. Rustad: The distribution of DNA among dividing mitochondria of Tetrahymena pyriformis. J. Cell Biol. 37, 683693 (1968)

112. Plesner, P., L. Rasmussen \& E. Zeuthen: Techniques used in the study of synchronous Tetrahymena. in: Synchrony in Cell Division and Growth, E. Zeuthen ed., Interscience Publ., New York-London-Sydney, pp. 543$563(1964)$

113. Porter, P. \& J. J. Blum: On the regulation of tyrosine transaminase, glytamic dehydrogenase and aspartic transaminase in Tetrahymena. Exp. Cell Res. 77, 335-345 (1973)

114. RickETTS, T. R. \& A. F. RAPPITT: A radioisotopic and morphological study of the uptake of materials into food vacuoles by Tetrahymena pyriformis GL-9. Protoplasma 86, 321-337 (1975)

115. Rosenberg, H.: The isolation and identification of "volutin« granules from Tetrahymena. Exp. Cell Res. 41, 397-410 (1966)

116. Rosenberg, H. \& N. Munk: Transport phenomenon associated with the deposition and disappearance of pyrophosphate granules in Tetrahymena pyriformis. Biochim. Biophys. Acta 184, 191-197 (1969)

117. Roth, L. E. \& O. T. Minick: Electron microscopy of nuclear and cytoplasmic events during division in Tetrahymena pyriformis strains $\mathrm{W}$ and HAM3. J. Protozool. 8, 12-21 (1961)

II8. RyLEY, J. F.: Studies on the metabolism of the protozoa. 3. Metabolism of the ciliate Tetrahymena pyriformis (Glaucoma piriformis). Biochem. J. 52, 483-492 (1952)

119. Ryley, J. F.: Carbohydrate and respiration. in; Chemical Zoology. I. Protozoa, G. W. Kidder ed., Academic Press, New York-London, pp. 55-92 (1967)

120. SATIR, B.: Membrane events during the secretory process. in: Transport at the Cellular Level, M. A. Sleigh \& D. H. Jennings eds., Symp. Soc. Exptl. Biol. 28, 399-418 (1974)

121. SatiR, B. \& E. R. Dirksen: Nucleolar aging in Tetrahymena during the cultural growth cycle. J. Cell Biol. 48, 143-154 (1971)

122. SatiR, B., C. Schooley \& P. SatiR: Membrane reorganization during sekretion in Tetrahymena. Nature 235, 53-54 (1972)

123. Satir, B., C. Schooley \& P. SatiR: Membrane 
fusion in a model system. Mucocyst secretion in Tetrahymena. J. Cell Biol. 56, 153-176 (1973)

124. Scherbaum, O. H. \& M. R. Levy: Some aspects of the carbohydrate metabolism in relation to cell growth and cell division. Path. Biol. 9, 514-517 (1961)

125. Scherbaum, O. H. \& E. Zeuthen: Induction of synchronous cell division in mass cultures of Tetrahymena pyriformis. Exp. Cell Res. 6 . $221-227(1954)$

126. Schultz, T. W. \& J. N. Dumont: Cytotoxicity of synthetic fuel products on Tetrahymena pyriformis. I. Phenol. J. Protozool. 24, 164172 (1977)

127. Shargo, E. \& C. Elson: Intermediate metabolism of Tetrahymena. in: Biochemistry and Physiology of Protozoa, 2nd ed. M. LevanDOWSKY \& S. H. Hutner eds., Academic Press, New York, Vol. III pp. 287-312 (1980)

128. SkRIVER, L. \& J. R. NiISSON: The relationship between energy-dependent phagocytosis and the rate of oxygen consumption in Tetrahymena. J. Gen. Microbiol. 109, 359-366 (1978)

129. Sмiтh, J. D. \& J. H. Law: Phosphatidylcholine biosynthesis in Tetrahymena pyriformis. Biochim. Biophys. Acta. 202, 141-152 (1970)

130. Stelly, N., M. Balmefrézol \& A. Adoutte: Diaminobenzidine reactivity of mitochondria and peroxisomes in Tetrahymena and in wildtype and cytochrome oxidase-deficient Paramecium. J. Histochem. Cytochem. 23, 686-696 (1975)

131. Stone, G. E. \& O. L. Miller: A stable mitochondrial DNA in Tetrahymena pyriformis. J. Exp. Zool. 159, 33-38 (1965)

132. Sutherland, A., G. A. Antipa \& C. F. Ehret: Ultracytochemical observations of glycogen synthesis and storage during infradian growth of Tetrahymena pyriformis. J. Cell Biol. 58, 240-244 (1973)

133. Suyama, Y.: The origin of mitochondrial ribonucleic acids in Tetrahymena pyriformis. Biochemistry 6, 2829-2839 (1967)

134. Suyama, Y. \& J. Eyer: Ribonucleic acid synthesis in isolated mitochondria from Tetrahymena. J. Biol. Chem 243, 320-328 (1968)

135. Suyama, Y. \& J. Hamada: The mitochondrial and cytoplasmic Valyl tRNA synthetases in Tetrahymena are indistinguishable. Arch. Biochem. Biophys. 191, 437-443 (1978)

136. Suyama, Y. \& K. Miura: Size and structural variations of mitochondrial DNA. Proc. Nat. Acad. Sci, U.S.A. 60, 235-242 (1968)

137. Suyama, Y. \& J. R. Preer: Mitochondrial DNA from protozoa. Genetics 52, 1051-1058 (1965)

138. TiedtKe. A.: Capsule Shedding in Tetrahymena. Naturwissenschaften 63, 93-94 (1976)

139. Thоmpson, G. A.: Studies of membrane formation in Tetrahymena pyriformis. I. Rates of phospholipid biosynthesis. Biochemistry 6 , 2015-2022 (1967)

140. Tokuyasa, K. \& O. H. Scherbaum: Ultrastructure of mucocysts and pellicle in Tetrahymena pyriformis. J. Cell Biol. 27. 67-81 (1965)

141. Turner, G., D. Lloyd \& B. Chance: Electron transport in phosphorylating mitochondria from Tetrahymena pyriformis. strain ST. J. Gen. Microbiol. 65, 359-374 (1971)

142. Weidenbach, A. L. S. \& G. A. Thompson: Studies of membrane formation in Tetrahy. mena pyriformis. J. Protozool. 21, 745-751 (1974)

143. Williams, N. E. \& J. H. Luft: Use of a nitrogen mustard derivative in fixation for electron microscopy and observations of the ultrastructure of Tetrahymena. J. Ultrastr. Res. $25,271-292$ (1968)

144. WunderLich, F. \& V. SPETH: Membranes in Tetrahymena. I. The cortical pattern. I. Ultrastr. Res. 41, 258-269 (1972)

145. Young, P. G. \& N. P. Hunter: Products of mitochondrial protein synthesis in Tetrahymena. Can. J. Biochem. 57, 314-320 (1979)

146. Yuyama, S. \& A. M. Zimmerman: RNA synthesis in Tetrahymena. Temperature-presure studies. Exp. Cell Res. 71, 193-203(1972)

147. Zeuthen, E.: Synchrony in Tetrahymena by heat shocks spaced a normal cell generation apart. Exp. Cell Res. 68, 49-60 (197I)

148. Zeuthen, E. \& L. Rasmussen: Synchronized cell division in protozoa. in: Research in Protozoology, T.-T. Chen ed., Pergamon Press, Oxford-New York, Vol. IV pp. 9-145 (1972) 